\title{
Singularidades museológicas de uma tábua com esculturas em diálogo: do alambamento ao casamento em Cabinda (Angola)
}

\section{Maria do Rosário Antunes Rodrigues Martins ${ }^{1}$ Ana Cristina Pessoa Tavares ${ }^{2}$}

RESUMO: Em Cabinda (noroeste de Angola), uma região do antigo Reino do Congo, existiu uma ancestral tradição gráfica observada em artefatos do cotidiano ou rituais que tem sido objeto de pesquisas em domínios multidisciplinares. O presente artigo remete para uma das possíveis reflexões em torno de uma tábua frustemente esculpida em alto-relevo, de que se desconhecem outros espécimes, e que integra a coleção recolhida pelos Missionários do Espírito Santo, atualmente em depósito no Museu da Ciência da Universidade de Coimbra. Não foi o valor estético que nos seduziu mas sim entender o seu significado, provocação que encontrou resposta na obra de José Martins Vaz, No mundo dos Cabindas, único suporte encontrado, até à data, que divulga a interpretação gráfica da peça e descodifica os motivos escultóricos. Esse objeto reflete um acordo de casamento e corporiza ideias, expressas por formas gravadas e símbolos, detentores de saberes tradicionais, intrinsecamente associados ao riquíssimo acervo da cultura material, incluindo a caixa nkobe-bingu, divindade protetora da família. Portadora de um significado singular, a tábua ou dístico de casamento espelha a dificuldade de acordo entre as famílias dos noivos quanto ao alambamento a negociar e sela o tradicional contrato de matrimónio dos Cabinda, etnia aparentada com o povo Kongo. Não sendo possível comparar com outras interpretações, o estudo desenvolvido permitirá compreender melhor o universo espiritual Cabinda refletido nas suas criações artísticas. Alargando horizontes de pesquisa, a tábua proporcionou um exercício museológico para o entendimento da realidade social da sua génese e de rituais de casamento de outros povos, em várias épocas.

PALAVRAS-CHAVE: Cultura material e imaterial. Alambamento. Casamento. Missionários do Espírito Santo. Angola.

Museological singularities of a board with sculptures in dialogue: from the alambamento to marriage in Cabinda (Angola)

ABSTRACT: In Cabinda (north-west of Angola), a region of the kingdom of Congo, there was an ancient graphical tradition observed in quotidian artifacts or rituals, about which several studies in multidisciplinary areas have been released. Not knowing other similar specimens, this
1. Pesquisadora do Museu de Ciência da Universidade de Coimbra. Centro de Investigação em Antropologia e Saúde (CIAS). Largo Marquês de Pombal, Coimbra, Portugal.E-mail: martinsr@ antrop.uc.pt

2. Conservadora das coleções de História Natural do Museu de Ciência da Universidade de Coimbra. Centro de Estudos Farmacêuticos (CEF). Largo Marquês de Pombal, Coimbra, Portugal.E-mail: actavar@uc.pt. 
3. Este exemplar integrou a exposição Da cartografia do poder aos itinerários do saber, apresentada pelo Museu Afro Brasil, em 2014, no edifício OCA, Parque Ibirapuera, São Paulo, Brasil. article refers to one of the possible reflections around a high relief carved board and it is part of a collection gathered by the Missionários do Espírito Santo currently at the deposit of Science Museum (Coimbra University, Portugal). It was not the aesthetic value that seduced us, but understand its meaning, provocation that found response in José Martins Vaz' book, No mundo dos Cabinda, only support found to date, which discloses the graphic interpretation of the piece and decodes the sculptural motifs. This object reflects a marriage agreement and embodies ideas expressed by sculpted forms and symbols, holders of traditional knowledge intrinsically associated with the rich collection of material culture, including one nkobe-bingu box, the family protective divinity. Carrying a singular meaning, this wedding board expresses the difficulty of the agreement between the bride and the groom families on the alambamento (dowry) to negotiate and it seals the Cabinda's traditional marriage contract, being this people related to the Kongo ethnicity. Not being possible to compare with other interpretation, this study will led to a better understanding of Cabinda's spiritual universe, reflected in their artistic creations. Broadening horizons of research, the artifact provided a museological exercise for understanding the social reality of its genesis and of marriage rituals of other populations in distinct time-frames.

KEYWORDS: Material and immaterial culture. Alambamento. Marriage. Missionários do Espírito Santo. Angola.

\section{Introdução}

A história das coleções africanas dos museus prende-se na maior parte das vezes com aquisições ou doações, em diversas circunstâncias e épocas, realizadas por viajantes, exploradores, administrativos, militares, comerciantes e missionários que contribuíram com informações sobre a produção, usos e costumes, dados relevantes para o estudo dos objetos.

Este artigo tem por base a recolha de espécimes etnográficos realizada pelos Missionários do Espírito Santo, congregação que teve um papel importante na região de Cabinda.

Entre outros missionários destacamos a figura do Padre José Martins Vaz (1924-20 1 1), licenciado em Filosofia e Teologia, nomeado para a Arquidiocese de Luanda em 1948. Durante dez anos esteve em contato direto com diversas populações, particularmente em missões na região do enclave de Cabinda (Maiombe, Cabinda e Lândana), onde reuniu objetos, contos, provérbios e adivinhas, material que proporcionou diversas publicações.

A coleção etnográfica recolhida ao longo de vários anos veio a integrar o Museu do Instituto Superior Missionário de Carcavelos (Portugal), encontrando-se atualmente em depósito (cerca de novecentos exemplares) no Museu de Ciência da Universidade de Coimbra.

Do acervo destaca-se, pela peculiaridade e desconhecimento de objetos semelhantes, um dístico ou tábua ${ }^{3}$ do povo Cabinda, esculpida em alto-relevo (Figura 1), reproduzindo um acordo de casamento, provavelmente recolhida no 
início do século XX e que se encontra descrita na obra de José Martins Vaz, ${ }^{4}$ No mundo dos Cabindas.

$\bigcirc$ povo Cabinda é um grupo bantu ${ }^{5}$ contido no grupo etnolinguístico kikongo, incluído na grande etnia Kongo que abrange várias áreas geográficas ao longo da costa ocidental de África (sul do Gabão, províncias angolanas do Zaire e do Uíge, República do Congo, enclave de Cabinda e República Democrática do Congo).

Para melhor compreensão e contextualização histórica, social, política e religiosa sobre a origem complexa do povo Cabinda e a sua íntima relação com a etnia Kongo, tentaremos explicar no capítulo seguinte a génese, intercâmbios socioculturais e os processos de reafirmação cultural a que esses grupos estiveram sujeitos.

tema apresenta uma das possíveis interpretações socioculturais em torno deste objeto que inclui a representação da caixa nkobe-bingu, divindade protetora que assume um papel importante no seio de cada família.

\section{Contexto histórico, social, político e religioso do povo Cabinda}

Onclave de Cabinda é limitado ao norte pela República do Congo, a leste e ao sul pela República Democrática do Congo e a oeste pelo Oceano Atlântico.

Para a contextualização histórica é importante referir que, no final do século $X V$, aquando da chegada dos portugueses a Santo António do Zaire, todos os terrenos para norte, sul e interior do rio Zaire formavam o Reino do Congo, não constando, porém, que os portugueses tivessem percorrido a baía de N'Goio, um condado sujeito ao potentado Manicongo ou "Mwene Kongo", significando Senhor do Congo.6

Apesar de a origem do Reino do Congo não ser concordata por falta de documentos e ser baseada em tradições orais e dado que o país esteve dividido por um número impreciso de povos, régulos e príncipes, Cavazzi” atesta que: "Com o decorrer dos séculos, quer pela prepotência de alguns chefes, quer pela volubilidade dos povos, os vários domínios foram reunidos sob uma única coroa. Desta maneira parece trazer a sua origem o Reino do Congo".

Segundo Bastin, ${ }^{8}$ Mbanza Congo, antiga capital do Reino do Congo, situada a sul da embocadura do Zaire, era um centro estratégico político e florescente, atribuindo ao Ntotila, chefe supremo ritualmente investido, reconhecido e venerado, um controlo sobre as rotas comerciais que uniam e cruzavam desde longa data as regiões do norte e sul do rio Zaire, conservando Mbanza dya Ntotila um prestígio mítico junto de todos os grupos culturais dos Kongo. Mbanza Congo, nos finais do século XVI, recebeu a designação de São Salvador do Congo, nome que manteve até 1975, data da independência de Angola, voltando posteriormente à denominação de origem. ${ }^{9}$

A cultura dos Kongo ficou conhecida desde o fim do século XV graças à bibliografia que the foi dedicada. Por exemplo, a publicação da correspondência diplomática mantida pelas autoridades africanas com o rei de Portugal e o papa. ${ }^{10}$
4. Vaz (1970b, p. 256-259).

5. Os bantus formam um grupo etnolinguístico localizado principalmente na África subsaariana, englobando uma diversidade de subgrupos étnicos.

6. Franque (1940, p. 54-55).

7. Cavazzi (1965, p. 230).

8. Bastin (1994, p. 20).

9. Bastin (1994, p. 20).

10. Bastin (1994, p. 20). 
11. Franque (1940, p. 9-12).

12. Franque $(1940$, p. $15-$ 19).

13. Franque (1940, p. 3638).

14. Franque $(1940$, p. 6667).

15. Hilton (1983, p. 189).

16. Ferreira Diniz (1918, p.65).
José Franque, ${ }^{11}$ um dos escritores com profundo conhecimento da história colonial dos N'Goio (Cabinda), com base na documentação deixada pelo seu pai, D. Francisco Franque, doada por Batchi Nhongo, VIIII Rei do N'Goio, e nas notas que continuou a coligir relativas a fatos notáveis dos Cabinda, reconstituiv e publicou o passado desse reino.

Franque ${ }^{12}$ relata que, segundo a tradição, porventura a mais verdadeira, a fundação e origem do Reino de N'Goio se relacionam, em época remota, com a princesa Muam Poenha e os seus três filhos gémeos. Muam Poenha era irmã do rei do Congo, solteira, vivendo em mancebia oculta e dessa ligação ilícita nasceram três filhos gémeos, motivo pelo qual veio a ser expulsa da corte de S. Salvador do Congo por volta de 1735. Tempos decorridos, a princesa casa com o nobre Mibimbi Pucuta, enlace que vem a ser reconhecido e coroado pelo seu pai, rei do Congo, propondo à princesa Muam Poenha, ao marido e aos filhos que tomassem conta dos três reinos de N'Goio, Cacongo e Loango-Grande. Após vários reinados, lutas e investiduras, Muam Poenha terá dado origem a poucos reinados entre 1790 e 1800 .

Após a morte do último rei do N'Goio, o reino passou a ser governado por um conselho de fidalgos e pessoas de reconhecida respeitabilidade por serviços prestados à terra e ao rei, aos quais atribuíam tífulos e a missão de receberem a contribuição que os comerciantes pagavam aos reis do N'Goio (Cabinda). ${ }^{13}$

Com as sucessivas invasões de povos bantus, o Reino de N'Goio foi-se fragmentando, adquirindo usos e costumes de vários grupos étnicos, incluindo o dialeto dos povos que thes estavam próximos.

Em 1885, após a Conferência de Berlim e a assinatura do Tratado de Simulambuco, foi reconhecida aos portugueses a posse do enclave de Cabinda englobando vários terrenos a sul e leste do rio Zaire, dando origem ao Distrito do Congo como parte integrante da então província de Angola. ${ }^{14}$

Convirá clarificar que a literatura nem sempre é consentânea quanto à definição e à caracterização geográfica do povo Kongo. Segundo a opinião de Hilton, ${ }^{15}$ os Kongo são apenas as populações da área geográfica antigamente controlada pelo Reino do Congo, uma região limitada pelos rios Zaire, Nkisi e Dande e pelo Oceano Atlântico. No entanto, Diniz ${ }^{16}$ adverte para o fato de a circunscrição de S. Salvador do Congo, território com cerca de 9 mil quilómetros quadrados, ser ocupada por diversos povos. Para além disso refere a abrangência representada pelos Kongo, que se consideravam parentes de vários povos: habitantes do Congo Belga, populações que residiam no enclave de Cabinda, ao sul do Zaire, ao norte dos rios Lifune e Zenza e dos povos Jingas, Mahungos, Holos e Mussucos.

\section{1. Relação entre o povo Cabinda e o povo do Kongo}

Sob o ponto de vista étnico e pelo que foi anteriormente exposto, o povo conhecido por Cabinda, remontando ao povo de N'Goio (antigo Reino do Congo), 
extravasa os limites geográficos dessa região. Redinha ${ }^{17}$ determina o povo Cabinda

17. Redinha (1974, p. 19).

18. Hilton (1983, p. 189).

19. Vaz (1970b, p. 172-173). de Cabinda assinala-se a presença dum tipo de homem,
de diversas etnias, vulgarmente designado 'Cabinda'".

Poder-se-á considerar que o povo Cabinda é uma etnia intimamente relacionada e vinculada aos Kongo, etnia com uma maior dimensão cultural. $\mathrm{Na}$ verdade, as duas etnias pertencem ao mesmo grupo linguístico, o kikongo, são originárias do antigo Reino do Congo, do antigo Congo Belga latual República Democrática do Congo) e do Congo Francês (ex-Congo Brazzaville e atual República do Congo).

Uma vez que a etnicidade desses grupos não pode ser dissociada pela história que as uniu, as formas de organização social, económica e política, as crenças e os costumes também são intercambiáveis. A história das relações de parentesco entre os Cabinda e os Kongo tem sido dominada pela ideologia kanda, ou seja, grupos descendentes por via materna que controlam e legitimam a posse da terra. ${ }^{18}$ Daqui se releva uma forte componente matrilinear, presente nos Cabinda, onde o chefe de família é também o tio materno, o mais velho dos irmãos uterinos, traço de união familiar e de antepassados comuns: "depositário da autoridade clânica, o representante dos vivos e dos mortos, o sacerdote da religião tradicional". 19

De igual modo os aspectos religiosos e sociais reafirmam-se culturalmente entre esses povos por estarem alicerçados no sistema matrilinear, em que a família é constituída por todos os descendentes de um antepassado comum, respeitando o símbolo sagrado da família (bingu), objeto representado no dístico e que teremos ocasião de analisar.

Em cada etnia, e consoante os hábitos tradicionais, são realizadas diversas cerimônias rituais ou ritos de passagem marcando as diversas fases do indivíduo ao longo da vida desde o nascimento, adolescência, casamento e morte, culminando em festas com a participação de toda a coletividade.

Esses costumes são impregnados de visíveis significados de caráter religioso e social, por exemplo, o estilo de determinado vestuário, penteado, adorno, pintura corporal ou amuletos protetores, usados segundo a idade e o que significavam perante a sociedade.

Desses rituais destacamos a importância de que reveste a passagem à maioridade masculina através da circuncisão e da feminina pelos preceitos iniciáticos que têm de ser cumpridos, regras imprescindíveis para que sejam pública e oficialmente reconhecidos como novos membros adultos na sociedade.

A morte, a preparação do funeral e o enterramento entre os povos Cabinda e os Kongo são momentos para homenagear e honrar o falecido com cânticos e festas, sendo as cerimónias fúnebres mais ou menos grandiosas em função do seu status. Como esses povos não creem na morte natural (apenas um renascimento ou transformação para outra vida em comunhão com os antepassados), era prática colocar sobre a sepultura objetos da pertença do falecido, como espingardas, catanas, facas, enxadas, cadeiras, bacias, pratos, colheres etc., 
20. Ferreira Diniz (1918, p. 83).

21. Vaz (1970b, p. 294).

22. Franque (1940, p. 166).

23. Dias (1992, p. 54).

24. Cavazzi (1965).

25. Cavazzi (1965, p. 80-81).

26. MacGaffey (1983, p. 185). incluindo alimentos diversos e vinho de palma com a finalidade de o morto se poder alimentar e ter sorte na caça. ${ }^{20}$

Nessas sociedades as responsabilidades e ocupações familiares recaem sobre o casal, em que o homem ficará incumbido de proteger a mulher e filhos, representá-los nas questões sociais, assim como preparar as terras para as plantações, caçar, pescar, entre outras atividades relacionadas com a alimentação animal e oleaginosa. A mulher, símbolo da procriação e da fecundidade, terá a seu cargo os aspetos inerentes à preparação e colheitas da terra com vista a alimentar o lar. ${ }^{21}$ Contudo, segundo relata Franque, ${ }^{22}$ "voluntariamente, um Cabinda faz trabalhar as suas mulheres, os seus filhos e os escravos". A esse respeito convém salientar que, entre os Cabinda, existiam três classes sociais distintas, a nobreza, o povo e os escravos, com prerrogativas e poderes diferenciados.

\subsection{O povo Cabinda e a colonização de África (séc. XVI a XVIIII)}

O contexto desta narrativa sobre os Cabinda, história, cultura e etnicidades adjacentes não poderá ficar dissociado de um enquadramento mais amplo, mas não menos importante, sobre a ocupação e colonização da África Ocidental entre os séculos XVI e XVIII, com profundas transformações ocorridas na sociedade africana sob os interesses da Coroa portuguesa. Entre os séculos XV e XVII, África ficou marcada pelo tráfico negreiro e pela escravatura, "responsável por ter criado os preconceitos que ainda hoje persistem. Presunções quanto à superioridade europeia acentuaram-se à medida que o comércio de escravos aumentou". ${ }^{23}$

O aumento do tráfico de escravos que se verificou no século XVI, na costa africana ocidental, foi canalizado através de Mbanza Kongo, onde a corte veio a ser constituída por reis que indicaram os filhos de mulheres escravas a suceder-thes, apoiados por conselheiros e soldados escravos. No século XVII, a obra de Cavazzi, ${ }^{24}$ Descrição histórica dos três Reinos do Congo, Matamba e Angola, refere minuciosas informações nos aspetos históricos, geográficos e etnográficos indo ao encontro da argumentação anterior. Esse missionário capuchinho relata que: "a multidão de escravos que cada ano se tiram do Congo, a fim de irem trabalhar para as minas da América, em número de cerca de 15 000", número que não deverá parecer exagerado pois os "ricos compram tantas mulheres quantas podem manter" dando à luz com grande fecundidade, não sendo invulgar haver "pais com sessenta e até cem filhos... chegando alguns a vendê-los como escravos". 25

Curiosamente, verificou-se que a escravatura e a saída de grandes contingentes humanos da África para a Europa não só não reduziram a população africana, mas antes a aumentaram. Na verdade, a população em Angola no século XVIII era desproporcionalmente feminina porque os europeus preferiam escravos do sexo masculino. ${ }^{26}$ 
desenvolvimento matrilinear na estrutura social das populações costeiras da bacia do Congo, Zimbábue e Angola pode ser consequência do intenso e prolongado comércio do Congo, particularmente relacionado com o tráfico de escravos. ${ }^{27}$

São pertinentes as questões que Dias ${ }^{28}$ coloca ao interrogar

como é que os Africanos aprenderam e reagiram aos Europeus e à sua cultura durante os primeiros séculos de contactos? E, muito em particular, qual foi a resposta intelectual dos Africanos à introdução de uma nova riqueza material e à evangelização dos missionários cristãos nesse período?

Sabemos do impacto que tiveram as inúmeras conversões ao cristianismo nessa época, nomeadamente de reis, dignitários, chefes e outras elites a ponto de se estabelecerem relações diplomáticas com o Vaticano, como atrás foi referenciado.

A identidade e os valores culturais dos Kongo confundiam-se à luz da fé cristã e dos batismos, existindo várias interpretações e argumentos sobre os fatos e a realidade, já que para o rei e dirigentes do Kongo o cristianismo e a presença europeia representavam também uma particular fonte de poder espiritual e material. ${ }^{29}$ Porém, no início do século XVIII o cristianismo manteve o seu significado original como a força que legitimava uma realeza forte e absolutista com o objetivo de reunificar o Reino do Congo. ${ }^{30}$

A complexidade que reveste a história das sociedades africanas e das culturas existentes, antes e posteriormente aos contatos com os portugueses e europeus, ao comércio humano e material que ali foi operado, aos diversos meios de evangelização, ao poder político e espiritual, explicará, porventura, as alterações significativas e as consequências de todo um processo de colonização.

Dentre os artefatos do povo Cabinda pertencentes ao espólio do Museu da Ciência da Universidade de Coimbra, destacou-se pela sua originalidade uma tábua esculpida ou dístico de casamento. As escassas fontes de que dispomos para a abordagem etnográfica desse objeto não são explícitas quanto ao envolvimento ou intervenção, direta ou indireta, de algum missionário ou de qualquer outra entidade relativamente ao modo como foi confecionada ou utilizada naquela sociedade. Sabemos que o objeto atingiu o seu fim utilitário, sobreviveu até hoje em contextos museais, mas pouco sabemos sobre a sua biografia cultural. Mesmo nessas circunstâncias o objeto é suscetível de uma análise biográfica que aluda ao seu status, período, cultura e outras possíveis abordagens, tal como refere Kopytoff: ${ }^{31}$

Biographies of things can make salient what might otherwise remain obscure. For example, in situations of culture contact, they can show what anthropologists have so often stressed: that what is significant about the adoption of alien objects - as of alien ideas - is not the fact that they are adopted, but the way they are culturally redefined and put to use.

Será esse o ponto de partida para um discurso museológico e para a interpretação do dístico de casamento dos Cabinda.
27. MacGaffey (1983, p. 187).

28. Dias (1992, p. 255).

29. Dias (1992, p. 270).

30. Dias (1992, p. 287).

31. Kopytoff (1986, p. 67). 
32. Vaz (1970b, p. 256).

33. Vaz (1970b).

34. Phemba ou Pemba significa caulino branco, argila usada como símbolo de inocência e vida, cf. Barbosa (1989, p. 430)

\section{A tábua - dístico de casamento}

Compreender para onde nos transporta metaforicamente esse objeto, por analogias ou correspondências, só fará sentido perante a lógica tradicional africana e a explicação das suas manifestações culturais, sendo exemplo a importância da negociação para a concretização de um casamento. Para além da vertente material referiremos adiante, noutro capítulo, o elemento espiritual inserto na tábua, expresso na caixa nkobe-bingu, onde estão reunidos os deuses tutelares das famílias.

Reporta Vaz ${ }^{32}$ que esse dístico de boas-vindas era colocado em dois paus, à entrada do recinto festivo para a realização do casamento:

existiam três dessas histórias que, em tempos tinham servido para outros tantos casamentos. Levamo-las de aldeia em aldeia a fim de conseguirmos a sua explicação. Duas delas nunca mais as vimos... A terceira acompanhou-nos até à Metrópole e oferecemo-la ao Museu do Instituto Superior Missionário de Carcavelos [...]

e atualmente está em depósito no Museu de Ciência da Universidade de Coimbra.

Por desconhecimento de outras fontes iremos basear-nos na perspetiva de $V_{a z}{ }^{33}$ para a descrição do objeto, cientes, no entanto, de poder não corresponder à total abrangência desse sistema de representações codificadas (Figura 1), de que não se sabe a autoria.

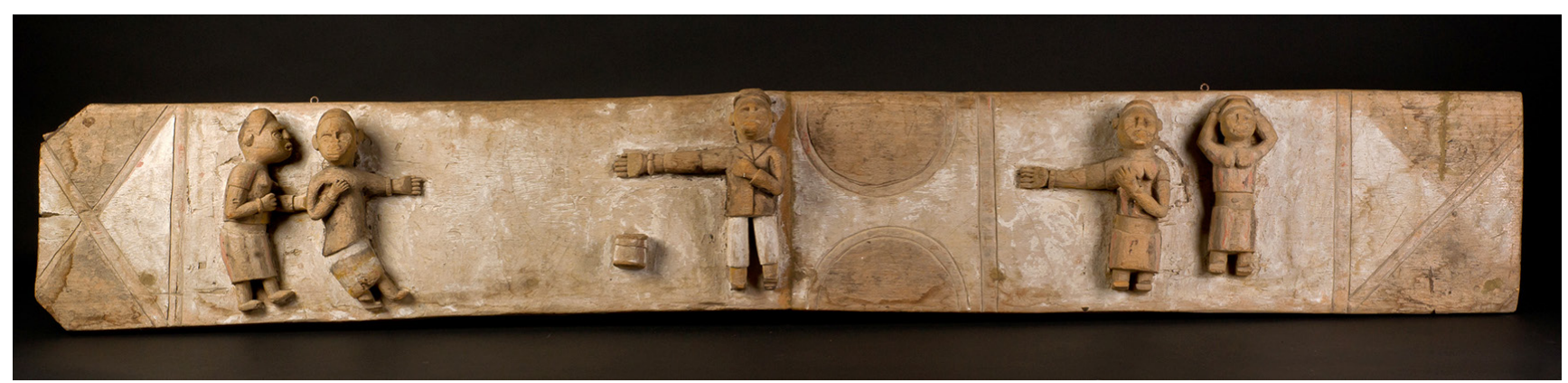

Figura 1 - Tábua, dístico de casamento. Cabinda. Angola. Depósito dos Missionários do Espírito Santo, 1984. ANT.D.84.1.433. $168 \mathrm{~cm} \times 26 \mathrm{~cm}$. Acervo do Museu da Ciência da Universidade de Coimbra. Fotografia de Bruno Pires.

A tábua ilustra uma história gravada em madeira, retangular, pintada parcialmente com caulino branco (phemba) ${ }^{34}$ e traços esbatidos a vermelho e preto. Apresenta cinco molduras de diferentes grandezas, divididas por barras verticais e seis elementos gravados em alto-relevo. Da esquerda para a direita, o primeiro setor é caracterizado por dois frisos duplos em cruz formando quatro triângulos de vértices unidos, diferenciados por duas tonalidades iguais nas superfícies diametralmente opostas. A segunda área mostra uma figura feminina de pé, com saia listrada na vertical a vermelho e preto, virada para a esquerda com a mão 
apoiada no antebraço de um indivíduo. Este apresenta o braço esquerdo estendido com a mão aberta e o outro dobrado sobre o peito, trajando calções com duas barras horizontais pintadas de branco. Mais à frente uma pequena caixa circular, junto de uma figura masculina, de pé, colocada de frente, envergando uma espécie de boné, fato com calças pintadas de branco, braço direito estendido com a mão aberta e, o outro, sobre o peito. As duas primeiras personagens dessa moldura diferenciam-se das outras por estarem de perfil, pela disposição lateral dos pés e inclinação do corpo. O terceiro quadro evidencia dois semicírculos duplos, afastados, diametralmente opostos, escurecidos no interior. A quarta moldura exibe uma figura frontal, feminina, de pé, com o tronco e a saia ornada com traços esbatidos a vermelho e preto, braço direito estendido e o outro sobre o peito. $\bigcirc$ último elemento, feminino, enverga uma saia semelhante à anterior, com as mãos entrelaçadas, apoiadas no alto da cabeça. $\bigcirc$ último quadro representa uma barra dupla oblíqua separando dois triângulos pintados em tons diferentes de castanho, diametralmente opostos, semelhantes aos do início da primeira moldura.

\section{1. Interpretação simbólica}

No seio de diversos povos africanos, nomeadamente no antigo Reino do Congo, existem testemunhos gráficos em que a escrita tomava várias formas, ilustrando crenças e valores. Para uma descodificação adequada dos artefatos, deve atender-se ao valor da oralidade em África, onde, tradicionalmente, a comunicação se praticava sob a forma da palavra, normalmente designada literatura oral: "a importância de precisar que a descrição dos testemunhos gráficos, em qualquer circunstância ou tipo de suporte, se desenvolvia com a precisão de identificar quem escrevia a quem, para transmitir o quê e em que contextos, embora com algumas exceções". ${ }^{35}$

Exemplo disso são as tampas de panela esculpidas em baixo-relevo do povo Woyo (região de Cabinda) com cenas e provérbios do cotidiano, desenhos na terra ou areia, imagens gravadas ou inscritas nos bastões de chefe ou em pedras sagradas mas, sobretudo, movimentos do corpo humano inscritos num gestual familiar. ${ }^{36}$

Convém salientar que o povo Woyo é um outro subgrupo da etnia Kongo, presente em Cabinda e na República Democrática do Congo e, segundo Lehuard, ${ }^{37}$ representa uma ínfima parte do Reino do Congo, vinte vezes mais pequena comparativamente com os Vili e Yombe, outros povos descendentes dos Kongo.

Entre os Woyo existia o costume de os pais oferecerem aos filhos testos ou tampas de panela entalhados transmitindo uma espécie de recados com signos codificados que traduziam orientações para conseguir uma boa relação conjugal, ter sensatez na escolha do cônjuge e estar alerta para as dificuldades do casamento. ${ }^{38}$ Para Gerbrands, ${ }^{39}$ essas tampas de panela eram, na maioria dos casos, cuidadosamente preservadas pelas mulheres idosas para usarem em diversas circunstâncias, lembrando "uma ocasião triste ou feliz na vida de casada".
35. Vaz (1969, p. 743-773).

36. Thompson (2002, p. 32).

37. Lehuard (1989, p. 323).

38. Vaz (1970a, p. 33-46; 57 158). O autor faz alusão a esses conselhos pré-matrimoniais retratados em diversas tampas de panela dos Woyo, testos oferecidos pelas famílias aos respetivos noivos antes do casamento.

39. Gerbrands (1957, p. 115). 
40. Miranda; Martins (2011, p. 464).

41. Thompson (2002, p. 43).

42. Thompson (2002, p. 105).

43. Vaz (1970b, p. 256-259).
À semelhança do simbolismo caraterizado nas tampas de panela dos Woyo, cuja mensagem é feita por analogia direta ou com recurso a uma versão metafórica ${ }^{40}$ e tomando como referente o desenho de Vaz (Figura 2), propomo-nos analisar a tábua e interpretar os motivos plásticos esculpidos na superfície, ou seja, encontrar um valor figurativo adequado ao contexto da narrativa que é ilustrada.

Nesse dístico, apesar de as esculturas evidenciarem um acentuado desgaste, ainda é possível observar uma forte componente do estilo tradicional Kongo, o que não será de estranhar, dadas as fortes interseções culturais entre os dois povos, como já referido. Assim, as figuras apresentam-se todas de pé, mostrando o rosto ovalado, olhos abertos, escavados, circundados por círculos, nariz proeminente, achatado, boca aberta ou rasgada, orelhas semicirculares em relevo (Figuras 7 e 8), sendo recorrente em todas as personagens uma espécie de chapéu alteado talhado em meia-lua e pulseiras num dos braços (Figuras 7 e 13). Verifica-se, também, que em quatro das cinco esculturas (exceção da última, a noiva) um braço está estendido e o outro colocado sobre o peito (Figura 11, uma das posturas gestuais emblemáticas dos Kongo.

Para Thompson, ${ }^{41}$ um dos especialistas da cultura Kongo, as barras ou traços pintados de vermelho (também patentes na tábua) indicam que poderão surgir problemas sérios, e a propósito de uma cabeceira de cama esculpida encontrada no nordeste do Maiombe (região de Cabinda) acrescenta: "les bandes rouges et noires tracées au-dessous des personnagens associent ce qui est secret (noire) au changement (rouge). Finalement, les forces rouges et noires s'entrelacent afin de sauvegarder une union et son avenir". ${ }^{42}$

O tema central desta longa história gravada na madeira está resumido no seguinte excerto: "houve quatro corações, quatro vontades, implicados no presente casamento: os noivos e as suas famílias. Inicialmente estavam em desacordo quanto à sua realização e quanto ao montante do dote [alambamento]. Os próprios noivos não sabiam o que fazer, pois não podiam ir contra o pensar dos seus parentes". 43

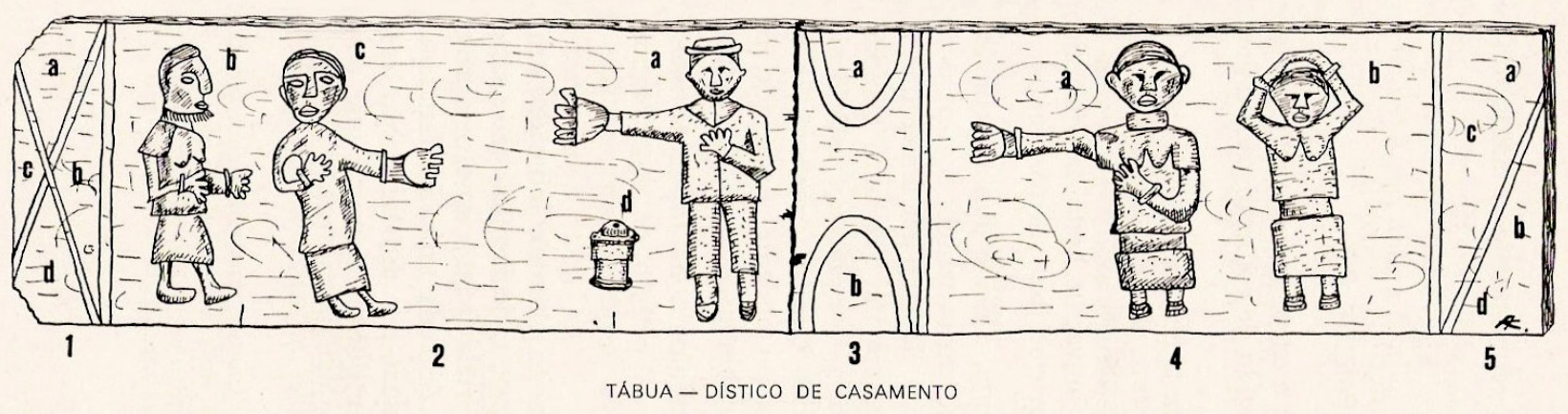

Figura 2 - Interpretação gráfica da tábua, dístico de casamento, retirado de Vaz (1970b). Fotografia de Maria do Rosário Martins. 
Segue-se uma exposição comparada e em detalhe das diferentes molduras da tábua (Figura 1), ilustradas e numeradas de 1 a 5 na interpretação gráfica (Figura 2) de Martins Vaz. ${ }^{44}$

Moldura 1: Duas barras duplas em cruz separam as duas famílias (Figuras 3 e 4):

a) representantes da família do noivo;

b) representantes da família da noiva;

c) noivo;

d) noiva.

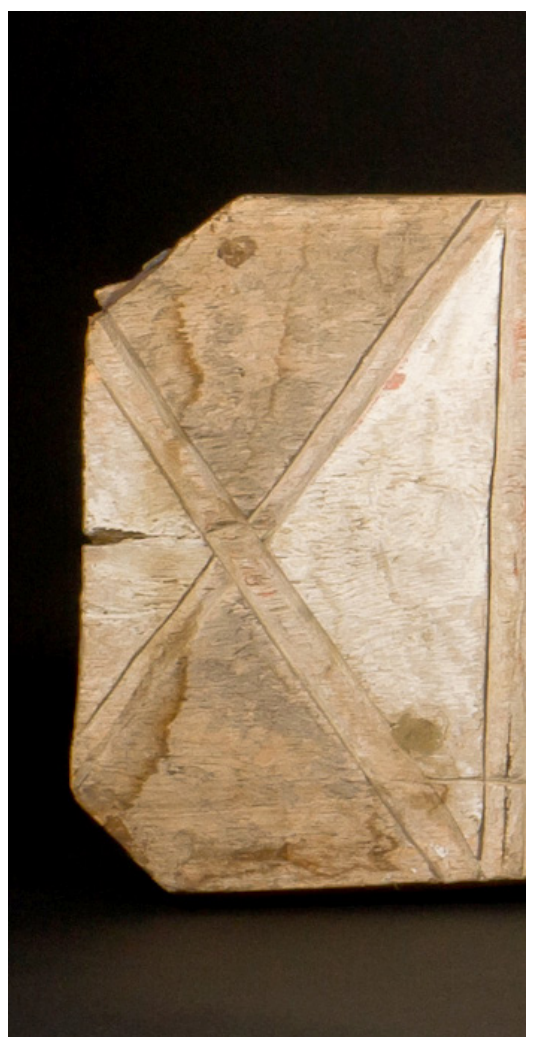

Figura 3 - Moldura 1 da tábua, dístico de casamento. Cabinda. Angola. Depósito dos Missionários do Espírito Santo, 1984. ANT.D.84. 1.433. Acervo do Museu da Ciência da Universidade de Coimbra. Fotografia de Bruno Pires.

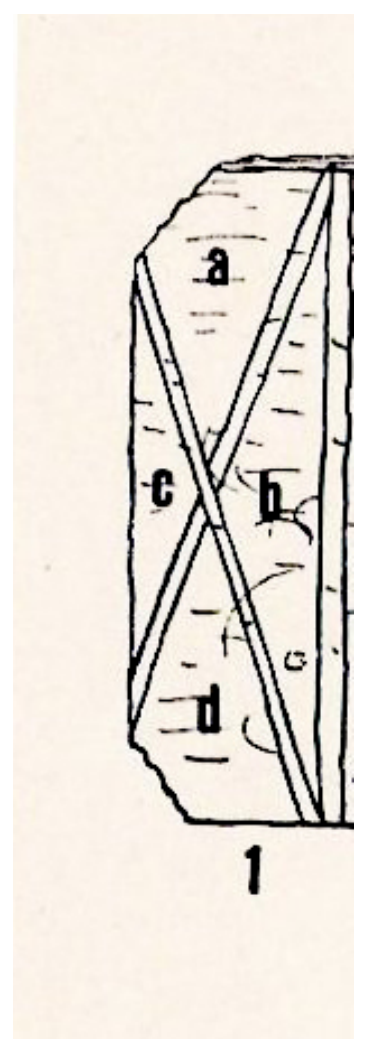

Figura 4 - Moldura 1, na interpretação gráfica da tábua, dístico de casamento, retirado de Vaz (1970b). Fotografia de Maria do Rosário Martins.
44. Vaz (1970b, p. 256-259).

45. Em cada moldura, a ordem alfabética corresponde à importância hierárquica familiar.

46,. Bingu é a designação local atribuída a uma caixa, símbolo sagrado e de união entre todos os membros da família com a mesma origem e consanguinidade. Vaz (1970c, p. 55).

Moldura 2: Representação de elementos da família do noivo ${ }^{45}$ e da caixa bing ${ }^{46}$ (Figuras 5 e 6):
a) tio materno;
b) mãe do noivo;
c) noivo;
d) feitiço familiar protetor, bingu. 


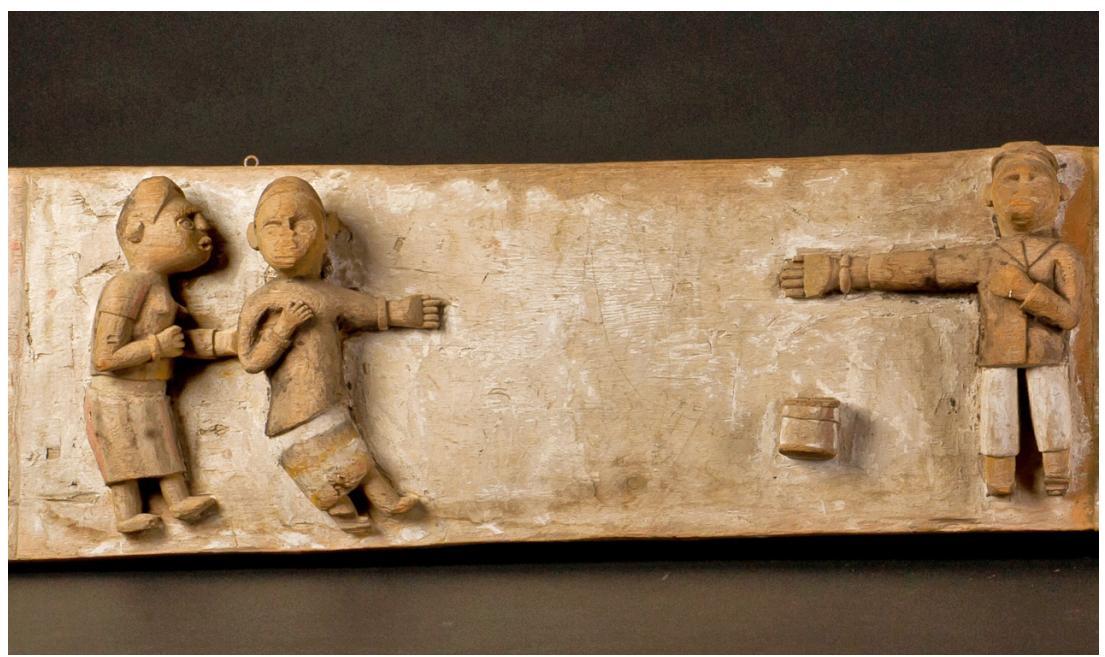

Figura 5 - Moldura 2 da tábua, dístico de casamento. Cabinda. Angola. Depósito dos Missionários do Espírito Santo, 1984. ANT.D.84.1.433. Acervo do Museu da Ciência da Universidade de Coimbra. Fotografia de Bruno Pires.

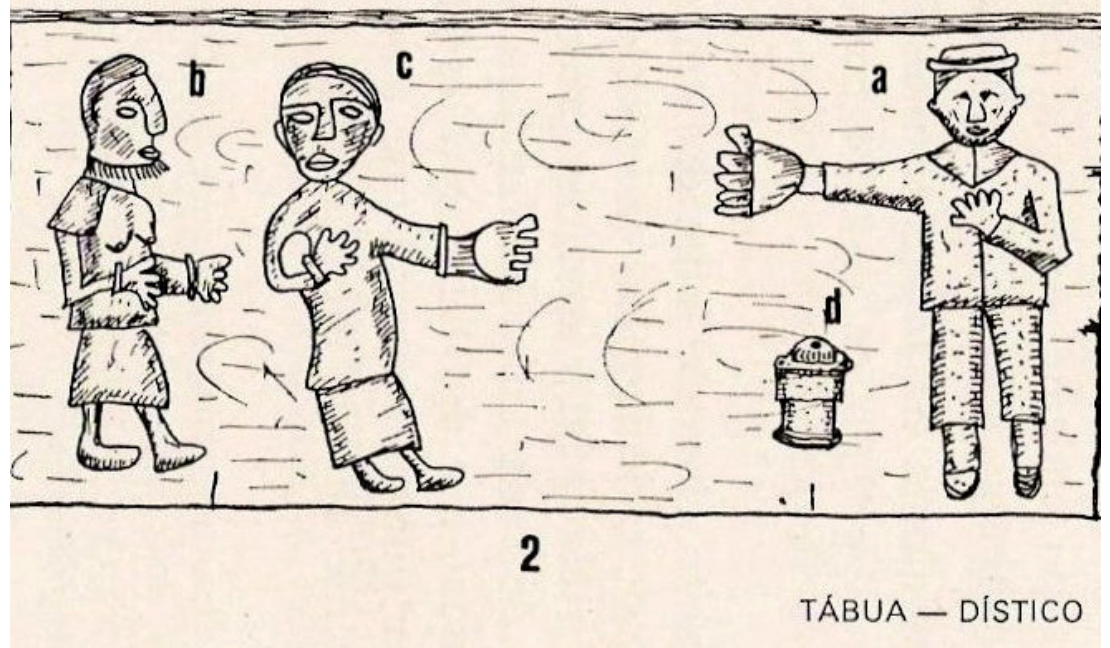

Figura 6 - Moldura 2, na interpretação gráfica da tábua, dístico de casamento, retirado de Vaz (1970b). Fotografia de Maria do Rosário Martins.

Mãe (b), filho (c) e tio materno (a) expõem as razões sobre o valor do noivo com o objetivo de conseguir que o alambamento solicitado pela família da noiva seja pouco elevado.

Esta é uma interpretação possível mas, provavelmente, não será a única. Na verdade e perante o papel importante do tio materno, do noivo ou da noiva, essa figura poderá representar qualquer das duas famílias nas quais é indispensável um mediador influente, sempre por via materna. 
No entanto, e como referimos, a tábua está dividida por molduras, 47. Vaz (1970b, p. 257). aparentemente independentes encerrando, porventura, elementos da mesma família (kanda) que, na moldura 2, será a do noivo, conforme interpretação de Vaz. ${ }^{47}$

Assim, parece-nos mais provável a hipótese de aqui estar representado o tio do noivo e não o tio da noiva, mediador imprescindível na negociação dos bens a dar pela família do noivo à família da noiva. Para além desse aspeto, a referida moldura mostra o bingu, forte elemento à guarda do tio materno que, nesse caso, será o da família do noivo. Embora não referida por Vaz, a inclinação do corpo e dos pés do noivo (c) e da mãe (b) parece-nos refletir um diálogo: a mãe segreda ao ouvido do filho, de quem não se quer separar, e mantém-no ligado a si pelo braço, como que a puxá-lo para ela (Figuras 7 e 8).

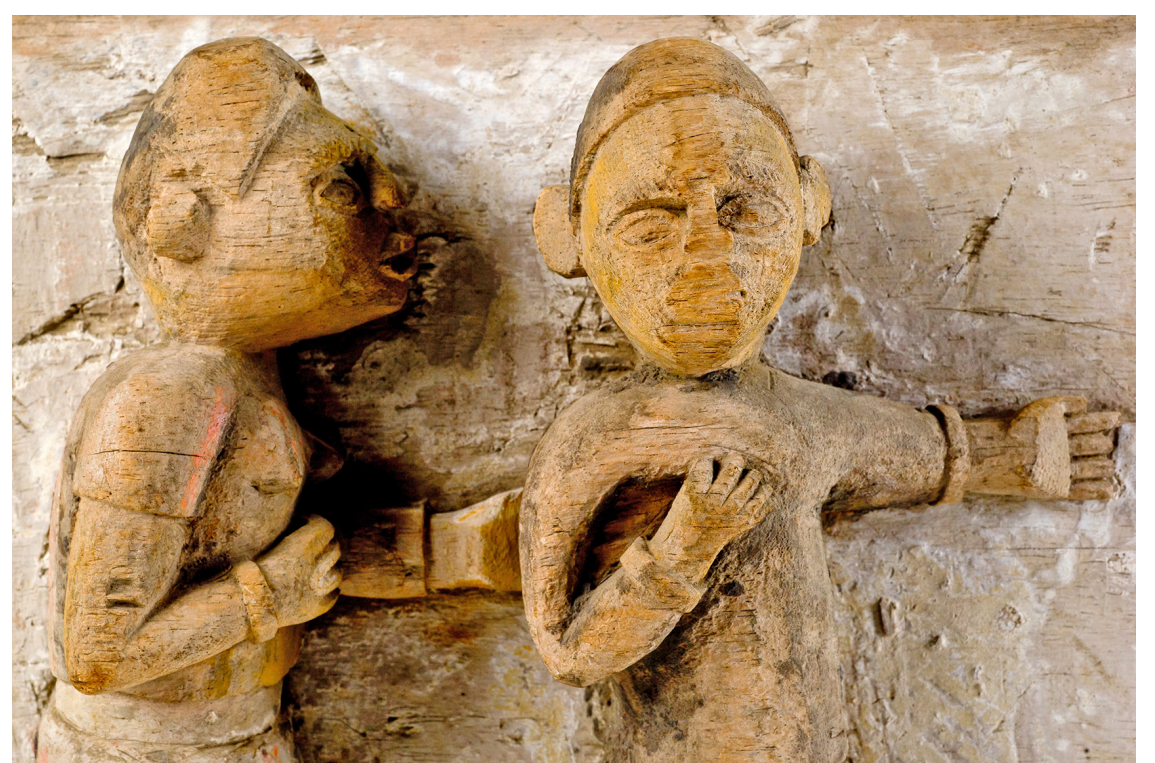

Figura 7 - Pormenores da moldura 2 da tábua, em que as esculturas representam a mãe a agarrar o filho. Tábua, dístico de casamento. Cabinda. Angola. Depósito dos Missionários do Espírito Santo, 1984. ANT.D.84.1.433. Acervo do Museu da Ciência da Universidade de Coimbra. Fotografia de Bruno Pires.

Figura 8 - Pormenores da moldura 2 da tábua, em que as esculturas representam a mãe a segredar ao filho. Tábua, dístico de casamento. Cabinda. Angola. Depósito dos Missionários do Espírito Santo, 1984. ANT.D.84.1.433. Acervo do Museu da Ciência da Universidade de Coimbra. Fotografia de Bruno Pires.

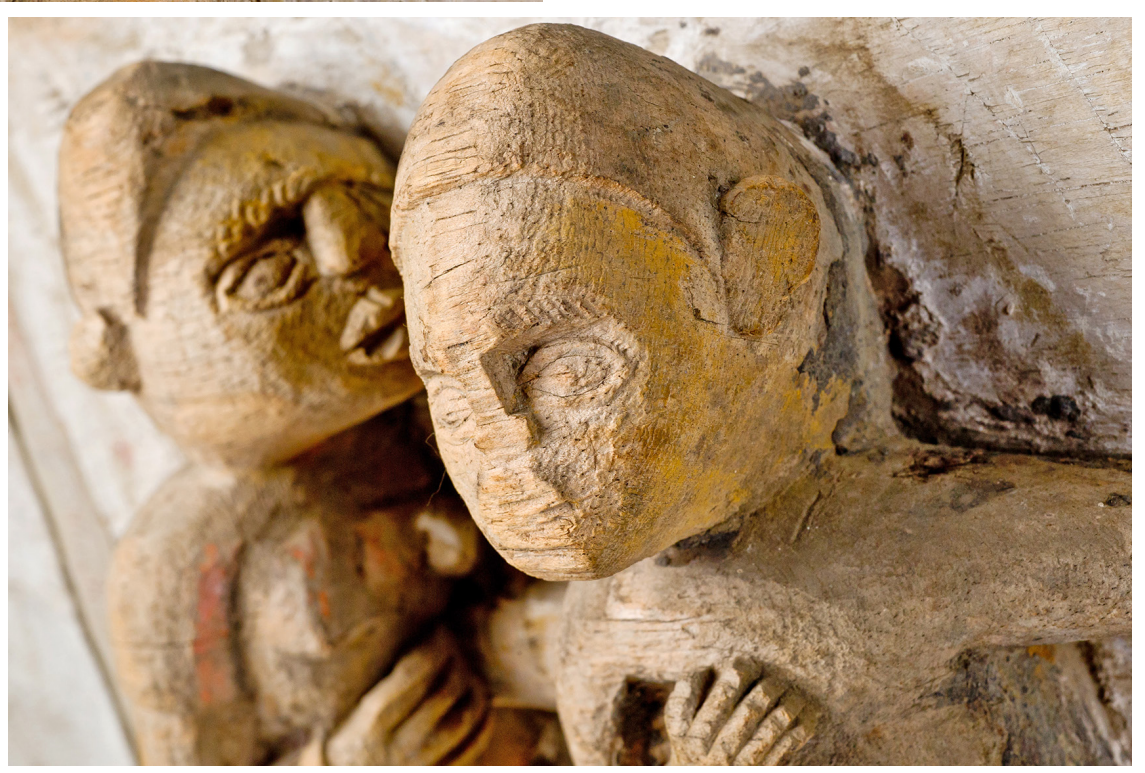


Esse pormenor que realçamos, explícito nas Figuras 7 e 8 , terá escapado à interpretação gráfica de Vaz (Moldura 2 - Figura 6), que mostra os dois elementos afastados.

Completam a Moldura 2 (Figuras 5 e 6) a caixa bingu (d) e o tio materno (a), sendo este o representante máximo da família e, por isso, o guardião dessas relíquias.

Moldura 3: Dois semicírculos a) e b) opostos indicam a área de residência de cada família, onde se situam as casas das várias mulheres e a residência principal. Cada grupo tenta mostrar o seu poder e valor - e os dos filhos que irão casar - com o intuito de obter uma aliança entre famílias (Figuras 9 e 10): a) e b) são semicírculos que figuram o cercado (lumbu) de cada família.

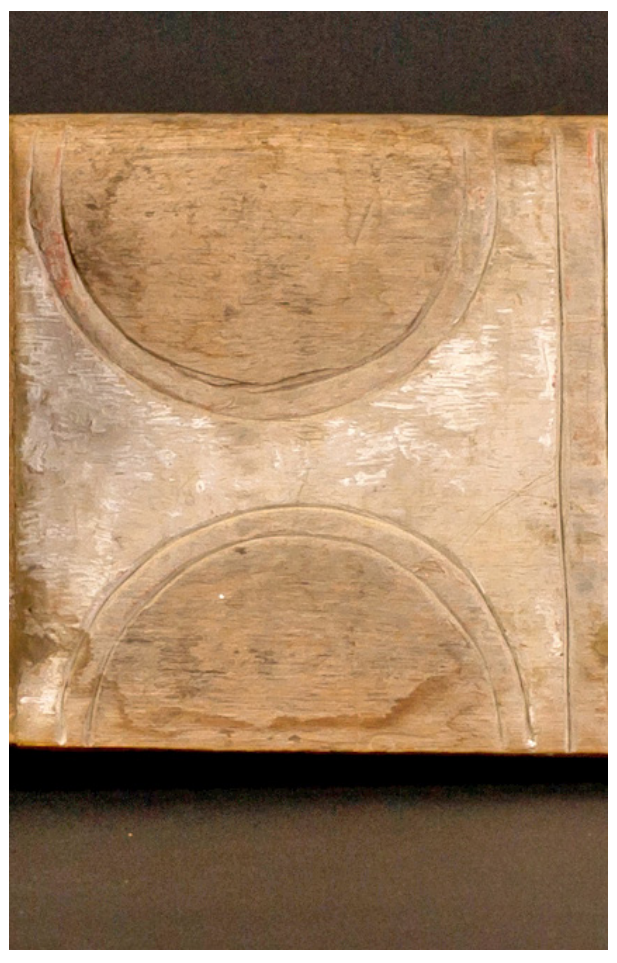

Figura 9 - Moldura 3 da tábua, dístico de casamento. Cabinda. Angola. Depósito dos Missionários do Espírito Santo, 1984. ANT.D.84. 1.433. Acervo do Museu da Ciência da Universidade de Coimbra. Fotografia de Bruno Pires.

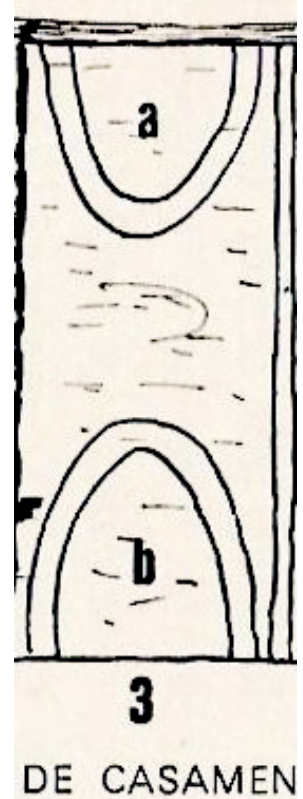

Figura 10 - Moldura 3, na interpretação gráfica da tábua, dístico de casamento, retirado de Vaz (1970b). Fotografia de Maria do Rosário Martins.

Moldura 4: Família da noiva (Figuras 11 e 12). A mãe a), com o braço direito esticado e o outro com a mão sobre o seio direito, contrapõe as suas razões e justifica a petição de um alambamento bastante elevado. A filha b) limita-se a ouvir a mãe e expressa de modo gestual, com as mãos entrelaçadas sobre a cabeça, a dor que the vai na alma (Figura 13). As duas figuras apresentam traços verticais pintados de vermelho, preto e resquícios de caulino branco (phemba):

a) mãe da noiva;

b) noiva. 

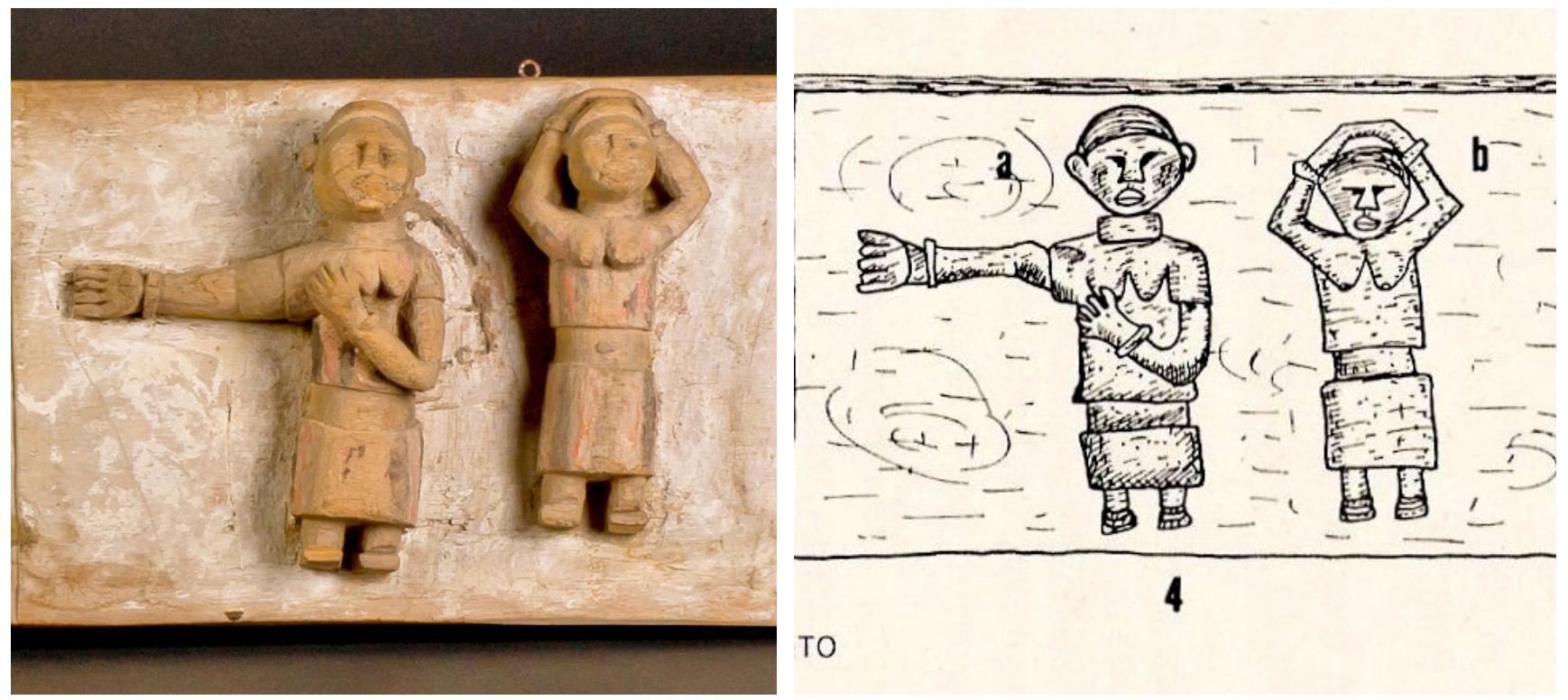

Figura 11 - Moldura 4 da tábua, dístico de casamento. Cabinda. Angola. Depósito dos Missionários do Espírito Santo, 1984. ANT.D.84.1.433. Acervo TO do Museu da Ciência da Universidade de Coimbra. Fotografia de Bruno Pires.

Figura 12 - Moldura 4, na interpretação gráfica da tábua, dístico de casamento, retirado de Vaz (1970b). Fotografia de Maria do Rosário Martins.

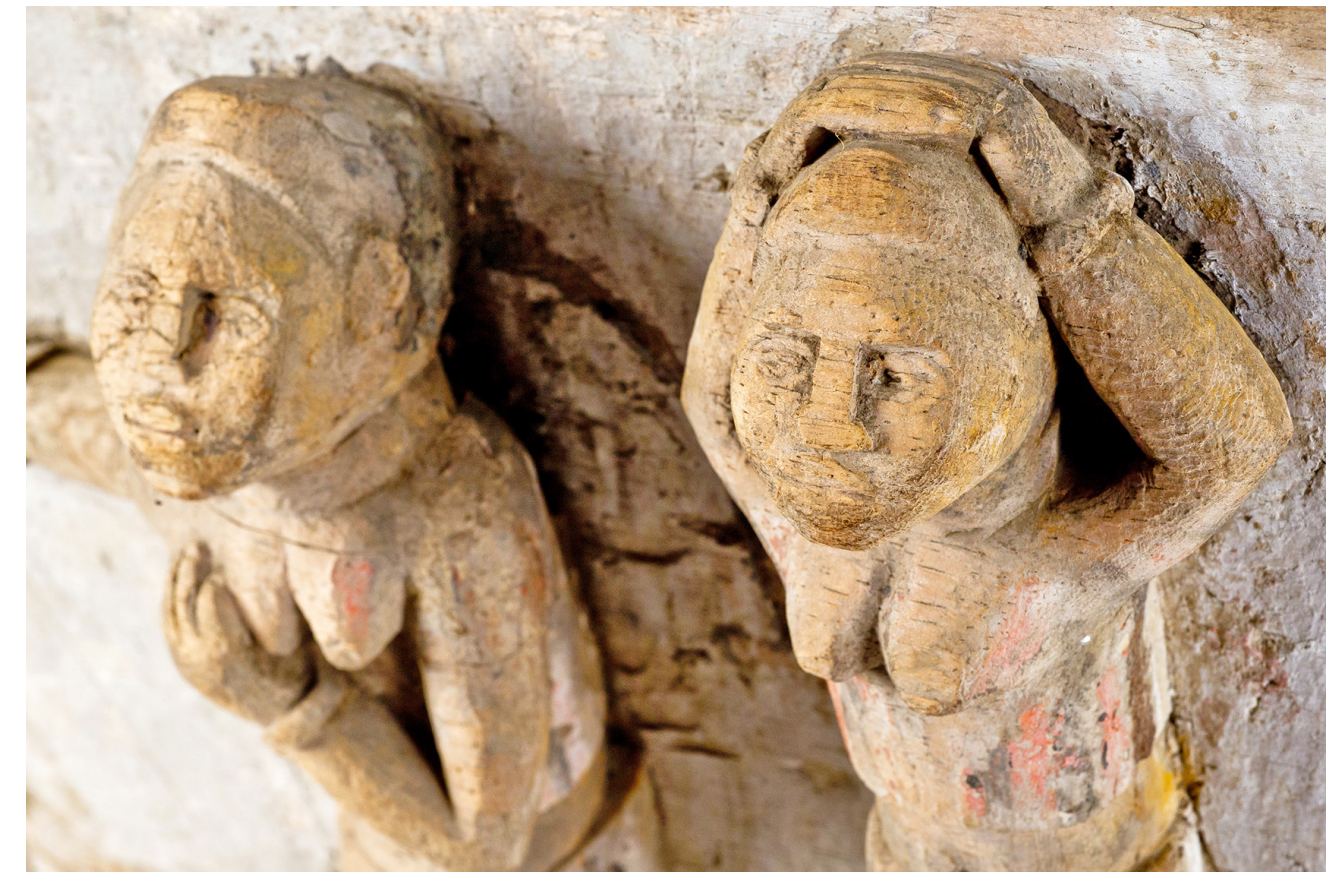

A dor expressa pela noiva é múltipla porque vai casar e deixar os seus, acabam os tempos sem preocupações, começam as responsabilidades do lar e ainda por temer ser estéril, motivos pelos quais deve aparentar melancolia, embora no seu íntimo esteja feliz por ter pretendente. Vaz ${ }^{48}$ explica que, segundo os usos
Figura 13 - Pormenores da moldura 4 na tábua, em que as esculturas representam a mãe com a mão no peito e a filha com as mãos na cabeça. Tábua, dístico de casamento. Cabinda. Angola. Depósito dos Missionários do Espírito Santo, 1984. ANT.D.84.1.433. Acervo do Museu da Ciência da Universidade de Coimbra. Fotografia de Bruno Pires.

48. Vaz (1970b, p. 258). 
49. Thompson (2002, p. 23).

50. Thompson (2002, p. 27).

51. Vaz (1970b).

52. Foi conseguido um acordo bilateral quanto à realização do enlace a comemorar por ambas as famílias (Figuras 14 e 15).

53. Vaz (1970b, p. 259). locais, a noiva deve assumir essa postura quando casa: "se eu mostrar alegria, mais tarde, se a vida me trouxer tristezas e me lamentar, dir-me-ão em tom sarcástico - Pois é, agora estás triste e chorosa, mas no dia do casamento bem te vimos toda foliona...".

Também Thompson, ${ }^{49}$ ao descrever em pormenor outros objetos, indica que os sinais das mensagens gestuais permitem aceder à profundidade dos seus significados: "Pour les Kôngo, les gestes créent des portes (bimwelo) menant à la compréhension. Les signes corporels constituent la mémoire et le reflect des expériences vécues". $O$ autor acrescenta ainda ${ }^{50}$ que a linguagem corporal dos kongo constitui uma forma de expressão muito elaborada, cuja interpretação é universal e reflete realidades transversais e atuais, como, por exemplo, o simples posicionamento das mãos sobre a cabeça: "les mains sur la tête, signe classique de devil associe au mot kyaadi, ou 'lamentation', et puis le signe kôngo traduisant l'extase", o que vem corroborar a opinião de Vaz. ${ }^{51}$

Este último quadro da tábua (Figura 14), tal como na Moldura 1 (Figura 3), revela quatro triângulos de vértices unidos, diferenciados por duas tonalidades iguais nas superfícies diametralmente opostas, com duas barras $(/ /)$ paralelas dispostas na diagonal.

Todavia, na interpretação de Vaz (Figura 15), o autor considerou os triângulos na primeira moldura (Figura 4) mas não os ilustra nesse último quadro (Figura 15), mantendo as linhas duplas que assinalam o acordo final. Apenas duas barras paralelas (//) separam os noivos c) e d) (Figura 15), indicando que estes continuam a pertencer às suas antigas famílias, respectivamente a) e b), não se formando uma nova porque, apesar de concordarem com o enlace, cada família continua a manter os seus interesses e conveniências:

a) família do noivo;

b) noivo;

c) família da noiva;

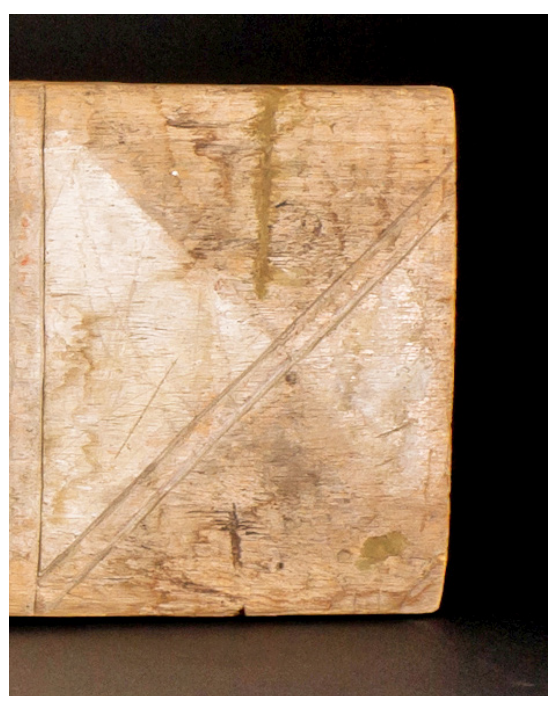

Figura 14 - Moldura 5 da tábua, dístico de casamento. Cabinda. Angola. Depósito dos Missionários do Espírito Santo, 1984. ANT.D.84.1.433. Acervo do Museu da Ciência da Universidade de Coimbra. Fotografia de Bruno Pires.

Figura 15 - Moldura $5^{52}$ na interpretação gráfica da tábua, dístico de casamento, retirado de Vaz (1970b). Fotografia de Maria do Rosário Martins.

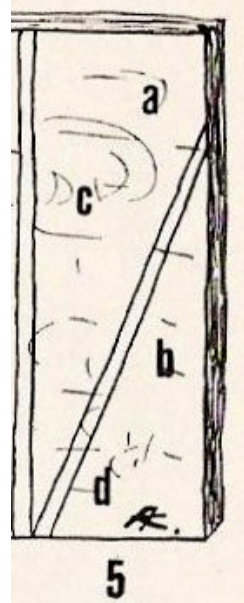

Anais do Museu Paulista. v. 25. n.2. Mai.-Ago. 2017. 
A explicação de Vaz, ${ }^{53}$ bem reforçada no gráfico da última moldura da tábua (Figura 15), remete-nos para outras vertentes sobre o casamento entre os Cabinda: "pelo casamento não nasce uma nova família, apenas as duas já existentes se solidificam e engrandecem: pela descendência futura que a família materna enquadra no seu âmbito; pela aliança que fazem entre si".

Na verdade, a razão fundamental do casamento é o progresso que dele advém, não para o indivíduo, mas para o clã, ao assegurar a continuidade e a multiplicação do mesmo, originando por vezes atritos familiares. Além de a filha (noiva) ser cedida ao noivo como doação definitiva, também se verifica o tabu entre sogra e genro, que pouco se comunicam, virando muitas vezes as costas um ao outro, ${ }^{54}$ costume que desconhecemos se ainda se mantém.

\subsection{A guardiã da família, nkobe-bingu}

Dentre as esculturas exibidas na tábua, a nkobe-bingu, pela sua importância e papel no casamento dos Cabinda, merece uma abordagem específica.

Entre os Cabinda, o chefe de família (mfumu kanda) é a autoridade suprema e o representante dos antepassados, cabendo-lhe o poder de organizar a sua família (kanda):

É ele que oferece sacrifícios, intercede pela sua descendência em cerimónias religiosas nos templos e no lar. Todos os deuses tutelares (bakissi ba nsi), representados no bingu, divindade protetora da família (nkissi nsi), contido numa caixa (nkobe) cilíndrica... daí dizer-se, por vezes, nkobe-bingu para designar a divindade protetora, embora a tradução literal seja a caixa do bingu. Nele há restos do corpo dos antepassados mais ilustres e vários pós [restos mortais] tidos como benéficos, tais como ngunze [barro especial], mpezu [espécie de gesso], takula [vermelho, Peterocarpus tinctorius] ${ }^{55}$ [ou tukula ${ }^{56}$ ].

Quando existe necessidade de ser resolvido algum assunto familiar que envolva desavenças, ódios, invejas ou calamidades, recorrem ao chefe para que este possa apaziguar os ânimos através de rituais propiciatórios ou de ação de graças. Cada grupo familiar (kanda) de mesma origem e consanguinidade possui o seu próprio bingu. Por esse motivo nenhum homem pode casar com uma mulher da mesma kanda, do mesmo sangue materno, do mesmo bingu. ${ }^{57}$ Laman $^{58}$ também refere que no casamento entre os Kongo não se formam novas famílias porque o marido pertence a uma kanda e a esposa faz parte de outra kanda, situação bem patente na última moldura da tábua (Figuras 14 e 15).

bingu implicava diversas cerimónias rituais e não devia ser entendido como um "feitiço", mas como um princípio destinado a manter pessoas consanguíneas no mesmo grupo familiar: "em cada família havia um NgangaMbingo a quem estava confiado o cuidado de celebrar as cerimónias do bingu e de vigiar pelo cumprimento dos preceitos estabelecidos"; era ao cuidado do Nganga (operador espiritual) que confiavam a guarda do nkobe-bingu, em lugar especial e, dentro deste, encontravam-se por norma giz ou cal (mpezo), argila
54. Vaz (1970b, p. 260).

55. Vaz (1970b, p. 42).

56. Thompson (2002, p. 65).

57. Vaz (1970c, p. 55-56)

58. Laman (1957, p. 38).

59. Martins (1972, p. 130). 
vermelha (ngunzi), o fruto (nkungulo), folhas da planta mabata-bata ou polpa de dendém (nkanvi-uliá-mbembe). ${ }^{59}$

responsável por essas caixas com testemunhos dos antepassados tinha compromissos bem explícitos para com a sua kanda, cabendo-lhe o dever de manter a harmonia nas relações e resolver as disputas no seio da família. Como prestígio de chefia, consultava os adivinhos para apurar a causa das doenças, obtendo junto dos curandeiros as mezinhas necessárias; organizava também as cerimónias fúnebres e recebia em troca provas de respeito e deferência, sendo homenageado com frequentes oferendas. ${ }^{60}$

Pelo exposto verificamos a importância atribuída a cada nkobe-bingu, objeto privativo de cada família do mesmo sangue com a responsabilidade, entre outras, de fazer respeitar as imposições concernentes ao casamento e daí se explica a sua representação na tábua.

A caixa representada no dístico de casamento assemelha-se ao exemplar (Figura 16) recolhido pelos Missionários do Espírito Santo, atualmente também em depósito no Museu da Ciência da Universidade de Coimbra.

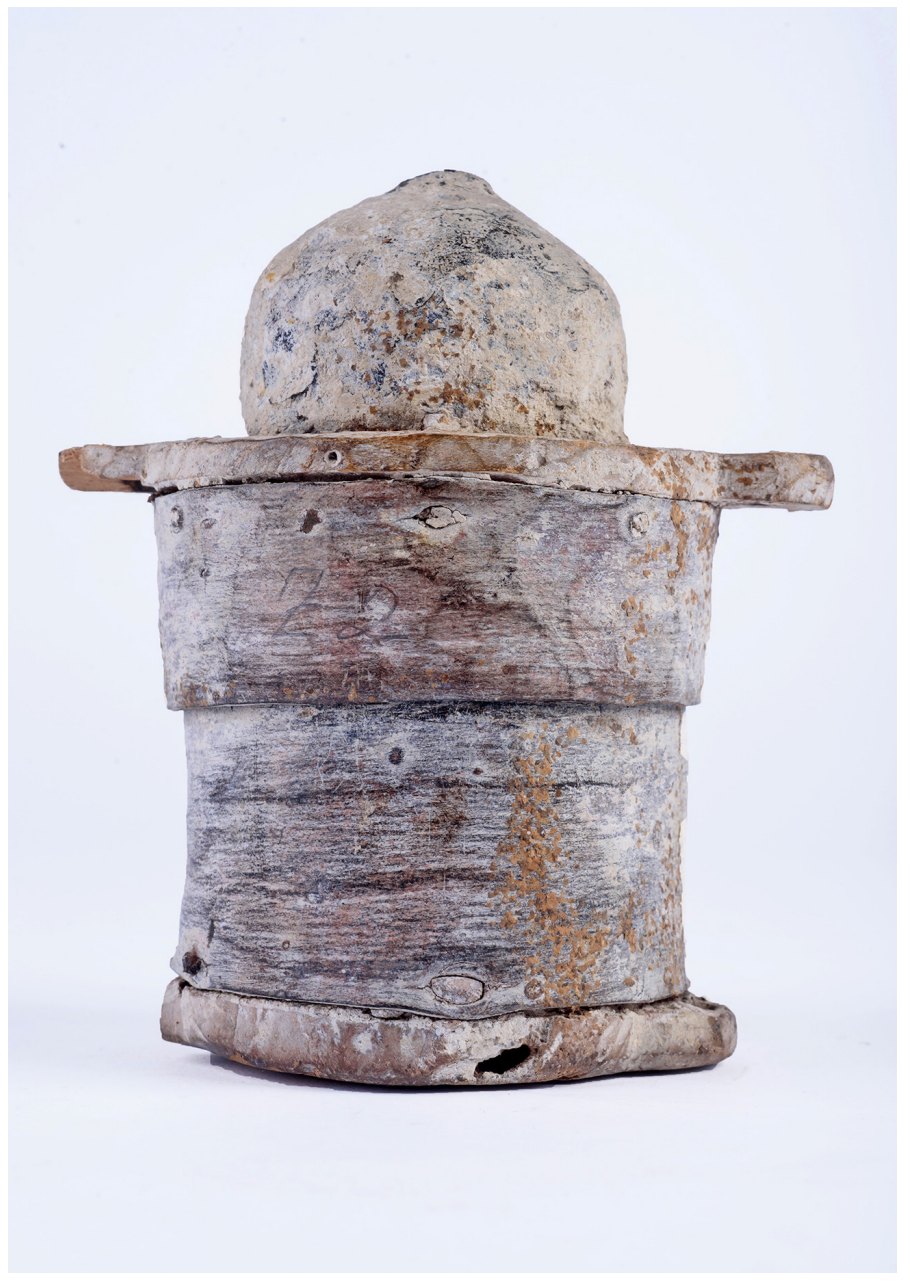

Figura 16 - Caixa, nkobe-bingu. Cabinda, Angola. Depósito dos Missionários do Espírito Santo, 1979. ANT.D.79.5.27. $13 \mathrm{~cm} \times$ $11 \mathrm{~cm}$. Acervo do Museu da Ciência da Universidade de Coimbra. Fotografia de Bruno Pires. 
Este artefato (Figura 16) é confecionado com delgadas lâminas de madeira ajustadas entre si, rematadas por fibras vegetais cosidas em ponto cadeia, assente numa base cilíndrica, com dois orifícios laterais.

Tampa feita de madeira, em calote esférica, encaixa pelo exterior, visualizando-se no topo uma pequena abertura (talvez para conter uma carga amulética desaparecida), exibindo dois pequenos orifícios diametralmente opostos e duas asas salientes, perfuradas ao centro, provavelmente para dar passagem a um fio de suspensão que prenderia a parte inferior à superior (Figura 17). $\mathrm{Na}$ superfície inferior está colada uma etiqueta, original dos registos dos Missionários do Espírito Santo, debruada a azul e branco, com a inscrição C-9-VI, remetendo para a ficha de inventário que acompanhou o objeto, informação que transcrevemos: "Feitiço protector da família. Dentro contém: terra, unhas de todos os familiares, cabelos, etc. Cerimónia: estando toda a família reunida o chefe de família abre a caixa e vai ungir as mãos de todos. Todos os que receberem esta unção são obrigados depois a ajudarem-se".

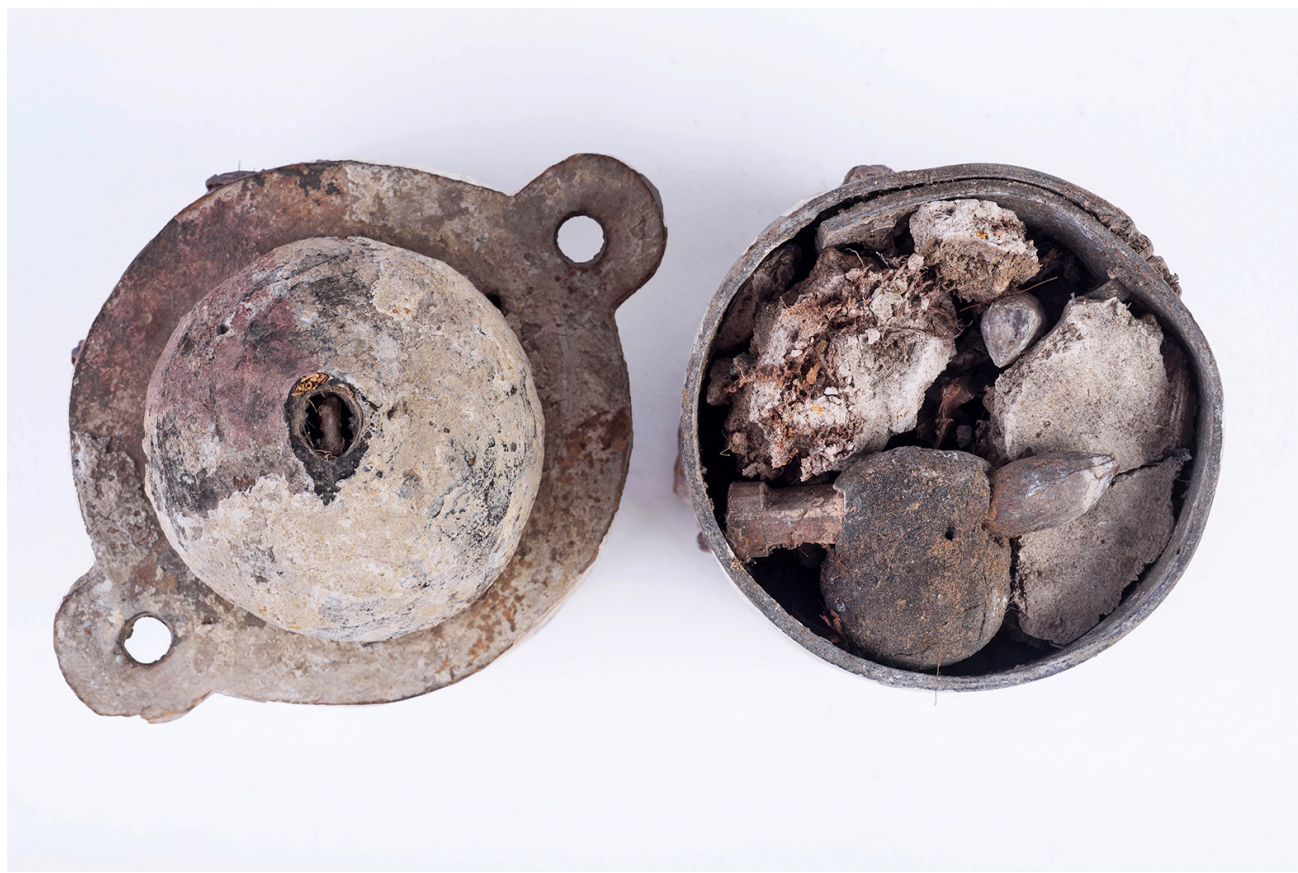

Figura 17 - Pormenor do conteúdo da caixa, nkobe-bingu. Cabinda, Angola. Depósito dos Missionários do Espírito Santo, 1979. ANT.D.79.5.27. $13 \mathrm{~cm} \times 11 \mathrm{~cm}$. Acervo do Museu da Ciência da Universidade de Coimbra. Fotografia de Bruno Pires.

No interior (Figura 17) ainda é possível visualizarmos restos de terra, unhas, cabelo, pedaços de caulino branco (phemba) e outros elementos que não conseguimos identificar. $\bigcirc$ conjunto está revestido por caulino branco (phemba), mostrando verticalmente vestígios de uma faixa pintada de vermelho ocre, pigmentações também presentes na caixa da tábua (Figura 4). 
Dadas a importância e a escassez de objetos similares em coleções museológicas, permitimo-nos incluir outras duas caixas, provavelmente nkobe-bingu, semelhantes à descrita; uma, recolhida igualmente pelos Missionários do Espírito Santo (Figuras 18 e 19) e a outra adquirida a Fernando Cabral Moncada em 1979 (Figuras 20 e 21 ).

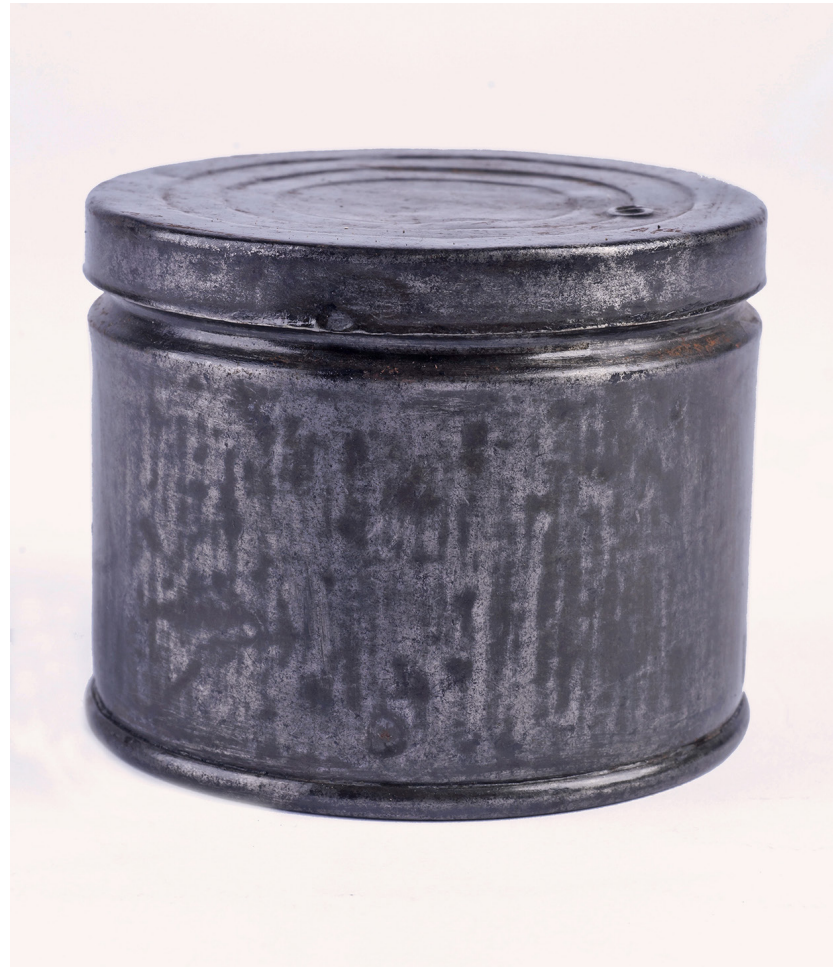

Figura 18 - Caixa, nkobe-bingu. Cabinda, Angola. Depósito dos Missionários do Espírito Santo, 1984. ANT.D.84.1.852. $6 \mathrm{~cm}$ $\times 7,3 \mathrm{~cm}$. Acervo do Museu da Ciência da Universidade de Coimbra. Fotografia de Bruno Pires.

Figura 19 - Pormenores da tampa e do conteúdo da caixa, nkobe-bingu. Cabinda, Angola. Depósito dos Missionários do Espírito Santo, 1984. ANT.D.84.1.852. $6 \mathrm{~cm} \times 7.3$ cm Acervo do Museu da Ciência da Universidade de Coimbra. Fotografia de Bruno Pires.
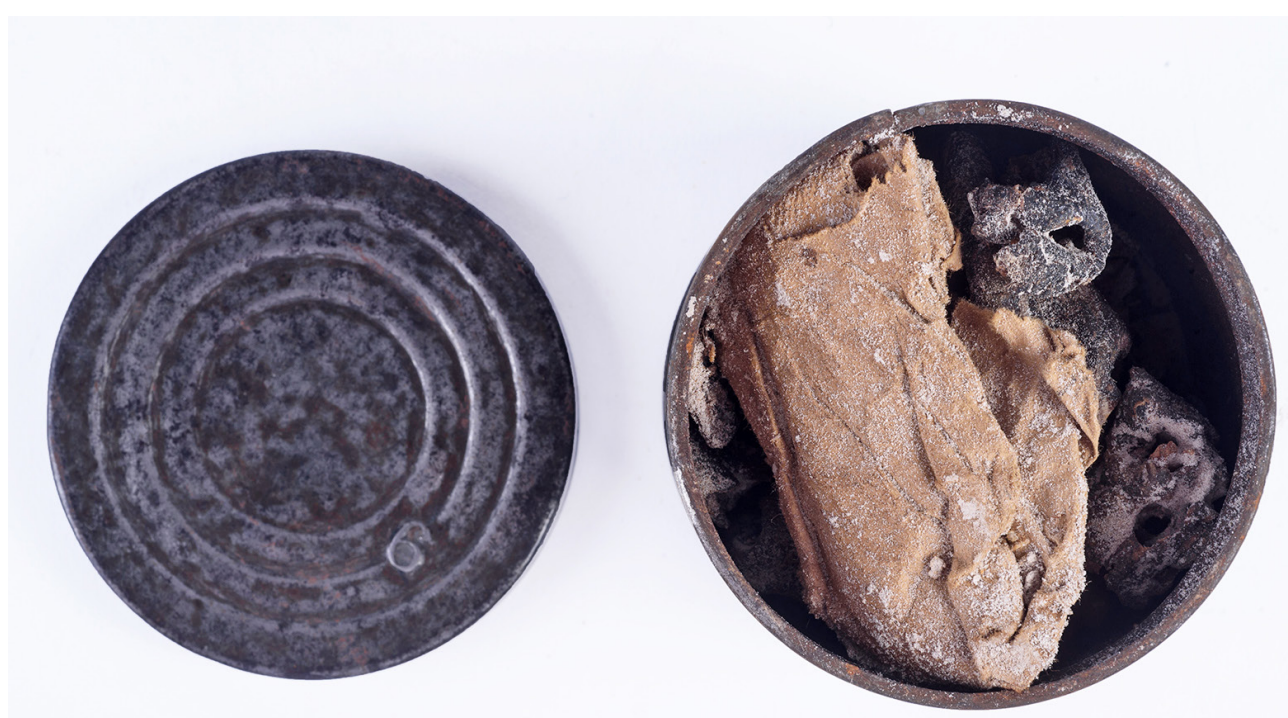
A caixa representada nas Figuras 18 e 19 é feita em folha de flandres, cilíndrica, com tampa de encaixar por fora, mostrando três círculos concêntricos no topo onde está gravado em relevo, no segundo círculo, o número 6 ou 9 , consoante à perspetiva. No interior contém inúmeros objetos, restos de patas de animais, ossos, unhas, tecido etc., envolvidos por uma substância terrosa avermelhada e uma espécie de caulino branco (phemba).
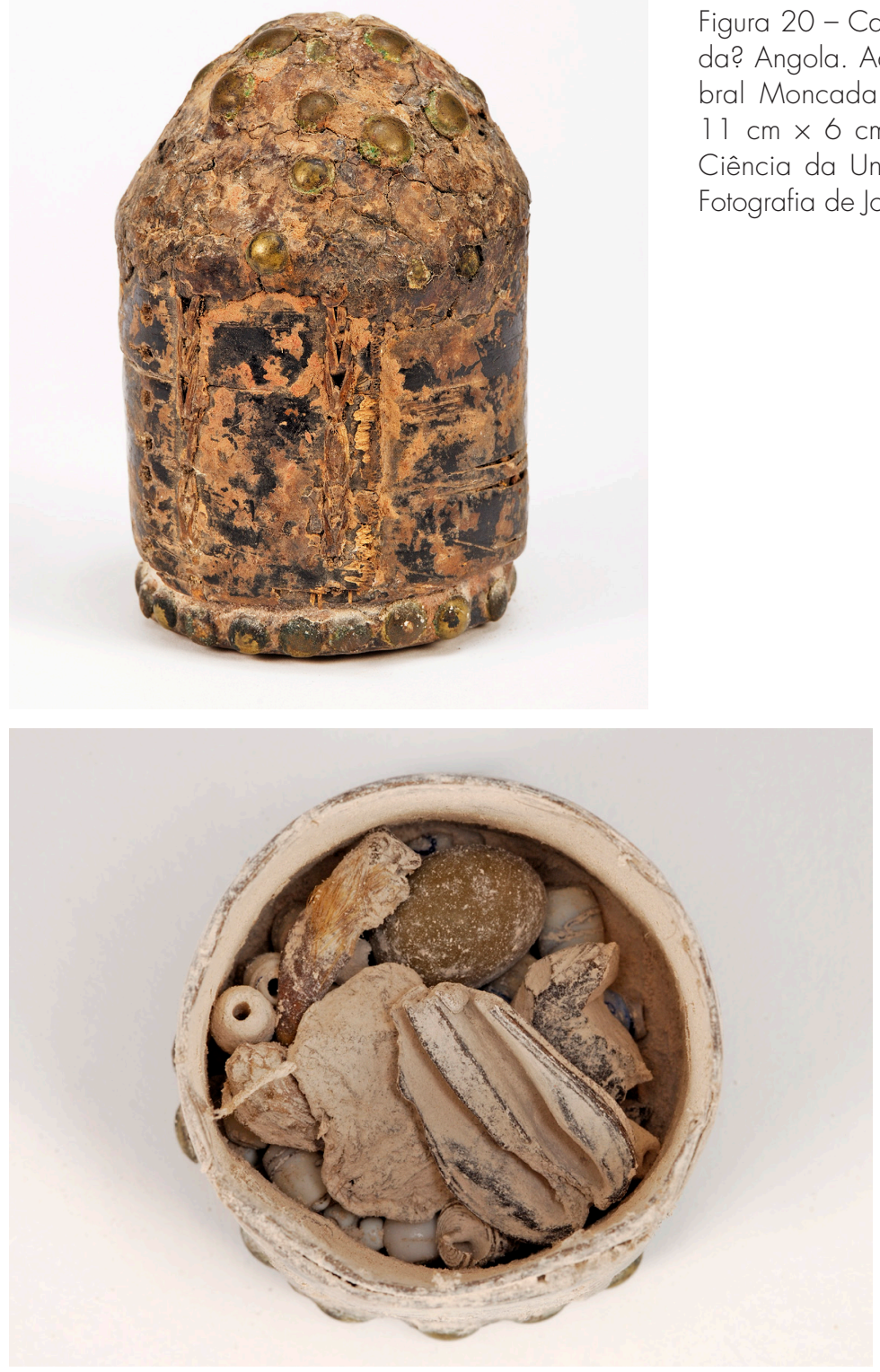

Figura 20 - Caixa, nkobe-bingu. Cabinda? Angola. Adquirida a Fernando Cabral Moncada, 1979. ANT.79.26.3. $11 \mathrm{~cm} \times 6 \mathrm{~cm}$. Acervo do Museu da Ciência da Universidade de Coimbra. Fotografia de José Meneses.
Figura 21 - Pormenor do conteúdo da caixa, nkobe-bingu. Cabinda? Angola. Adquirida a Fernando Cabral Moncada, 1979. ANT.79.26.3. $11 \mathrm{~cm} \times 6$ $\mathrm{cm}$. Acervo do Museu da Ciência da Universidade de Coimbra. Fotografia de José Meneses.

A Figura 20 mostra uma caixa cilíndrica, feita de largas fibras de entrecasca de árvore batida, com tampa de encaixe exterior até à base, rematada em tronco de cone, decorada com múltiplas tachas de latão e um pequeno cauri 
61. Martins; Cruz (1989, p. 27).

62. Lehuard (1977, p. 87).

63. Milheiros (1948, p. 2325).

64. Mbambi (2007, p. 1).

65. Valente (1985, p. 70).

66. Vissers (1964, p. 140141).

67. Bafiote e Asolongo são variantes linguísticas de povos que habitavam a margem esquerda do rio Zaire, admitindo outras grafias, como Fiote ou Sorongo, Musserongo. Redinha (1974, p. 18). branco incrustado no topo. O conjunto está totalmente revestido por resina e caulino branco (phemba) e a base decorada por uma fieira contínua de tachas de latão. No interior (Figura 21) possui múltiplas contas perfuradas de diversas dimensões, sementes, búzios e pedras, conteúdo envolto por resquícios de uma pigmentação vermelha e caulino branco (phemba).

É de salientar a importância atribuída ao cauri (Cypraea moneta), búzio largamente utilizado como ornamento ou amuleto cuja forma remete, simbolicamente, para o sexo feminino, para a fecundidade, riqueza e felicidade, tendo sido durante muito tempo utilizado como moeda de troca, generalizado a partir do século XVI em Angola, Congo e Guiné. 61

A diversidade de pequenos objetos rituais contidos nas caixas nkobebingu varia consoante as famílias e os grupos étnicos. Lehuard ${ }^{62}$ identifica em pormenor o conteúdo de uma caixa (Nkisi di Lemba) feita de entrecasca de árvore batida, recolhida na região do Maiombe (Cabinda), reforçando a importância da argila branca e da vermelha empregues nas pinturas rituais.

\section{Do alambamento (zibula munu) ao casamento}

O dístico de casamento transportou-nos para uma das possíveis interpretações antropológicas em várias vertentes. No entanto, a sua razão de ser depende diretamente de um só facto: o acordo para a realização de um casamento entre os Cabinda.

Nessa perspectiva entendemos também ser oportuno abordar a realidade dessas práticas entre as populações angolanas e ampliá-la a contexłos históricos e culturais de diferentes países e sociedades.

Em direito africano e reportando-nos a Angola, o casamento é um contrato sinalagmático, pelo qual o marido e a mulher se propõem perpetuar a descendência ${ }^{63}$ e pode ser celebrado de forma tradicional (alambamento), religiosa ou pelo civil.

O alambamento é tido como o ato que antecede o matrimónio, após ter sido feito o pedido da mão da noiva, considerado "a prova de casamento" no casamento tradicional, expresso na Portaria $n^{\circ}$ 6: 546 do Governo-geral da Colónia de Angola, em 22 de dezembro de 1948.64

Para Valente, ${ }^{65}$ a utilização do termo ovilombo para alambamento em língua umbundu (falada no centro e sul de Angola) parece não ser o mais correto, uma vez que lamba significa "apoderar-se de; consolar" e lomba "pedir". Ovilombo, substantivo formado pelo verbo lamba, significa "valores em dinheiro ou géneros dados aos pais da noiva", pelo que a palavra deveria ser alombamento e não alambamento ou alembamento.

O missionário espiritano Vissers, ${ }^{66}$ que dedicou treze anos ao estudo do alambamento na região de Cabinda, nomeadamente entre os Bafiote ${ }^{67}$ e Asolongo, refere-o como prova de que o noivo aprecia a noiva e deve conquistá-la com trabalho árduo. As razões que levam à concretização desse costume passam pela 
avaliação das qualidades de trabalho do indivíduo escolhido e da capacidade em conseguir o valor estipulado pelos futuros sogros, compensação material relativa à perda de uma filha que representa riqueza e uma fonte de receita pelo trabalho que desenvolve (a mulher como fonte de trabalho e de procriação).

A amplitude do alambamento é reforçada por Dittmer:68 "Ao casar-se uma rapariga a família perde, por assim dizer, um poder e valor económico. Para reparar esta perda o noivo tem que oferecer uma espécie de indemnização", sendo, também, a garantia de que o casamento durará e que a jovem será bem tratada e, se houver divórcio por maus-tratos do marido, não deveria então restituir-se nada ou pouco do alambamento. No entanto, a família da noiva fica obrigada a devolver a dádiva se o casamento não se consumar ou em caso de divórcio provocado pelo não cumprimento da missão da mulher, obrigando os pais da noiva a devolver total ou parcialmente os bens que thes tinham sido entregues pelos sogros. ${ }^{69}$

Em relação ao divórcio praticado em tempos no distrito de Benguela, Bastos $^{70}$ observou que o mesmo era permitido e frequente, fosse a pedido do marido, da mulher ou pela família desta através do tio materno, principalmente quando a mulher ao fim de dois anos não tivesse conseguido ter filhos e as irmãs casadas já os tivessem no mesmo período. Nessa circunstância, a jovem divorciada voltava para casa dos pais ou parentes para contrair novo matrimónio, esperando pelo alambamento do novo marido. Em caso de esterilidade atribuída ao marido, a mulher não podia casar novamente sem que o segundo marido restituísse ao primeiro o alambamento que este havia dado. No julgamento de crimes e delitos, a exemplo do adultério, existia sempre o pagamento de uma multa:

toma essa multa o nome especial de úkói, principalmente usado entre os Mundombes, Mucuandos e Quilengues [etnias do distrito de Benguela]. Estes três povos chegam a fazer d'isso uma exploração immoralíssima, induzindo as suas mulheres a commetter o adultério para receberem a multa respetiva. ${ }^{71}$

A prática do alambamento continua a ser realizada entre muitos povos africanos, considerada ainda em Angola como uma cerimónia fundamental no casamento tradicional, dependendo da etnia, da posição social das famílias, da fertilidade dos terrenos e das circunstâncias e épocas do enlace.

Como condição fundamental e tradição cultural ${ }^{72}$ para a tramitação do noivado em Cabinda, é estabelecido um conjunto de bens materiais, objetos, utensílios, vestuário, bebidas alcoólicas (por norma vinho de palma, aguardente, vinho abafado ou licoroso), um ou mais animais (bois, touros, galináceos), peixe seco, adornos, cobertores, cestos, esteiras, panelas, lenha, enxadas, catanas, óleos ou outros bens de consumo e, por vezes, uma razoável quantia em dinheiro, oferecidos pelo noivo à família da noiva para fazer face às despesas do banquete. $\bigcirc$ quantitativo é variável conforme a riqueza, idade, posição social da noiva, qualidades morais e físicas, de trabalho e o facto de a mulher ser virgem ou não.

A importância da mulher cabinda e em Angola em geral, associada à ideia de que deve ser fértil, é intuída pelas jovens desde muito cedo, fruto de
68. Dittmer (1960, p. 85)

69. Valente (1985, p. 71-72).

70. Bastos (1908, p. 85).

71. Bastos (1908, p. 91).

72. Em alguns grupos, o rapaz pede a um amigo que leve à rapariga uma prenda para uso pessoal. Por exemplo, um lenço para a cabeça; se ela guarda a oferta, mostra que aceita a "amizade", oficializada apenas depois de a família concordar. Martins (1972, p. 189). 
73. Miranda; Martins (2010, p. 91).

74. Vissers (1964, p. 139).

75. Valente (1985, p. 76-78).

76. Como a sociedade kongo é matrilinear (linhagem e sucessão por via materna), a força do sistema familiar é centrada na figura do tio materno.

77. Laman (1957, p. 25; 3436).

78. Os ritos de passagem ou de iniciação representam transições das diversas fases da vida de um indivíduo no seio de uma sociedade, acompanhadas por cerimoniais de caráter comunitário, social ou religioso, rituais ligados ao nascimento, circuncisão, casamento, morte ou investidura de um chefe.

79. Buza et al. (2011, p. 9).

80. Vaz (1970b, p. 255).

81. Durante a boda, a noiva devia demonstrar tristeza, quase não falava e só comia mais tarde, na cozinha. Vaz (1970b, p. 255). uma sensibilização protagonizada pelas mais velhas através da confeção e uso de amuletos, tais como bonecas de fertilidade "para proteger futuras mães e propiciar futuras descendências"73 e de inúmeros provérbios africanos que aludem a comparações entre o sol (homem) e a lua (mulher): "aparentemente o sol é mais importante, mas de facto a lua vale mais por ter filhos: as estrelas". ${ }^{74}$

Analisando o significado atribuído a cada etapa do longo processo concernente ao alambamento em Angola, Valente ${ }^{75}$ menciona que "para assegurar a noiva", o pai do rapaz, ou este, dirige-se à casa da rapariga levando consigo "presentes e valores dados à família da noiva para impedir que a deem a outro" e, se a petição for aceite, será sinal de um primeiro acordo. Caso contrário, o pedido é rescindido e os bens devolvidos. Quando o rapaz transmite à jovem escolhida os seus intentos e esta comunica aos seus pais, a relação será permitida se for do agrado dos futuros sogros, ficando a noiva comprometida em relação a eventuais pretendentes. Se o noivo oferece uma garrafa de vinho licoroso à noiva e ambos provam a bebida, significa que estão de acordo e que o pedido de casamento foi aceite reunindo-se, posteriormente, as duas famílias para darem o seu aval, decidirem o quantitativo e prazos de entrega do alambamento. Tradicionalmente, os pais da noiva recebiam apenas algumas ofertas e grande parte do valor angariado revertia para o tio materno, ${ }^{76}$ como expresso na obra do missionário Laman, ${ }^{77}$ que reforça a importância desse parente entre os Kongo nas decisões contratuais e garantias para o casamento, motivo que justifica a sua representação na tábua, dístico de casamento.

Se a primeira fase de negociação for ultrapassada com êxito procede-se à segunda, e com o pagamento dos valores em dinheiro, ou em géneros, terminam as obrigações e há garantias materiais para se proceder à cerimónia do casamento.

Um estudo recente revela que os rituais de passagem ${ }^{78}$ na região do enclave de Cabinda estão em extinção, mantendo-se, todavia, o alambamento, "fase substantiva do casamento tradicional que acabou sendo a aglutinação de todas as cerimônias que deveriam ser chamadas de iniciação". 79

Em Cabinda, as famílias dos noivos preocupavam-se com a organização do casamento e com os preparativos para o desenrolar da situação, sempre prontas a intervir em todos os detalhes sociais que a festividade envolvia. A cerimónia do casamento $^{80}$ realizava-se na presença das duas famílias, autoridades regionais, amigos e convidados, circunstância em que supomos ter sido exibida a tábua ou dístico de casamento em análise.

Face às leis locais, ficavam casados quando o noivo dizia para a noiva: tu simbana (demos as mãos), e ela respondia: ké tu bikana kó (não as separemos mais), iniciando-se a festa entre todos os convivas. ${ }^{81}$

Citando o Código de Família angolano (Lei $n^{\circ} 1$ de 1988), apenas o casamento civil concede efeitos jurídicos, especificados no Artigo 22: "A promessa de casamento, seja ou não acompanhada da entrega de bens ou valores ao outro nubente ou à sua família, não produz quaisquer efeitos jurídicos e não dá direito de exigir a celebração do casamento" e, quanto à validade (Artigo $27^{\circ}$, Lei no 
1/88), só será reconhecida quando celebrado perante órgãos do Registo Civil ou de acordo com as regras estipuladas por Lei.

Esses princípios estão a ser revistos atualmente, defendendo que a lei deve esclarecer a natureza jurídica do casamento tradicional e que o alambamento deve ser clarificado perante a mesma, no sentido de evitar o abandono das famílias e a fuga à paternidade. $\bigcirc$ processo de revisão do Código de Família deverá atender à realidade social angolana de forma a fazer convergir o direito com os costumes do povo, quanto à união de fato, de separação ou de divórcio.

Apenas em $2015^{82}$ a união de facto por mútuo acordo passou a estar regulada e aprovada pelo presidente da República de Angola, permitindo agilizar o processo de reconhecimento da vida em comum entre cidadãos nascidos no país.

casamento celebrado pelas autoridades tradicionais angolanas, como sobas e anciãos, vai passar também a ser autenticado legalmente, perante a proposta de reforma do Código de Família, que fixa os 16 anos como a idade mínima para casar. Quanto aos casamentos religiosos, somente os celebrados por instituições estatais serão reconhecidos.

Feita uma abordagem ao alambamento e sua forma de interação na sociedade angolana, convirá esclarecer que o sinónimo por vezes atribuído ao alambamento e ao dote pode ressaltar de uma equivalência de significados, explícito pelo "olhar europeu", por exemplo, do missionário Martins Vaz. ${ }^{83}$ Porém, a equivalência de significados é contestada por outro missionário espiritano ${ }^{84}$ que exprime uma opinião contrária quando afirma que: "Nunca o alambamento teve verdadeiramente o sentido que os europeus dão ao dote". Esse conceito parece-nos plausível tendo em conta as diferentes raízes culturais, residindo o alambamento entre os Cabinda na forte componente matrilinear, ao contrário da bilateralidade que define as relações de parentesco no Ocidente e na perspetiva do cristianismo.

Por esse motivo, e porque entendemos que não se devem igualar práticas que têm sentidos distintos consoante as diversas realidades e contextos culturais, achamos pertinente aludir ao papel que o dote assumia ao selar alianças entre as famílias, citando alguns exemplos concernentes a países de quatro continentes (Moçambique, Portugal, Brasil, Castela e Índia).

dote gera um vínculo ao casamento cujo valor pode assumir variantes étnicas e temporais, segundo os géneros de vida social. No entanto, as modalidades de compromisso mútuo, que incluem direitos e deveres recíprocos, não divergem das que são acordadas pelo alambamento.

Por exemplo, em Moçambique, o alambamento lque aqui se designa lobolol e o casamento, assuntos de famílias e não dos nubentes, são também legalizados pelo pagamento de uma compensação por parte do noivo à família da noiva. As fases cerimoniais do lobolo assemelham-se às praticadas pelos Cabinda (Angola), compondo-se, em regra, por uma determinada quantia em dinheiro, cabeças de gado, vestuário, bebidas alcoólicas e alfaias agrícolas e, em caso de divórcio motivado pela mulher, deverá ser devolvido em parte, ou no todo, ao marido. 
85. Polanah (1987, p. 9395).

86. Jacmin (1994, p. 61)

87. Jacmin (1994, p. 67).

88. Arras ou sinal é uma garantia, geralmente em dinheiro, de uma das partes para demonstrar o interesse e a veracidade em cumprir um contrato, podendo ser dada por meio de um bem em vez de dinheiro. Definição obtida nos artigos 417 a 420 do Código Civil brasileiro, de 2002, atualmente em vigor. Brasil (2002).

89. Dicionário (2008).

90. Aldazábal (2007).

91. Aldazábal (2007).

92. Seabra (1983, p. 44)
Contudo, há situações em que o lobolo, fonte de rendimento para os pais das raparigas, não se destina apenas a obter uma mulher para casamento, podendo ser reservado à aquisição de uma jovem para ser iniciada nos mistérios da possessão espiritual. .85

Noutras realidades, não africanas, em que os casamentos tradicionais são legitimados pelo dote (bens oferecidos pelo noivo aos pais da rapariga ou vice-versa), deparamo-nos com fatos perfeitamente alarmantes como, por exemplo, os que ainda hoje prevalecem na Índia. Nesse cenário, onde a dinâmica familiar e social coloca a mulher na dependência marital, as alianças conjugais são negociadas entre duas famílias que estipulam o quantitativo do regime dotal, relegando e subordinando a liberdade afetiva individual aos interesses em jogo. Cabe aos pais da noiva reunirem o dote necessário, durgavat lassim designado em sânscrito, antiga língua dos brâmanes). "Na Índia, o dote, apesar de proibido por lei, tem vindo a atingir, nas duas últimas décadas, valores incalculáveis, razão pela qual tem aumentado o infanticídio feminino e o aborto, chegando mesmo a verificar-se o assassinato da jovem noiva por falta de pagamento do dote" ${ }^{86} \mathrm{~A}$ morte "acidental" de uma esposa "incómoda" permite ao marido, agora livre, tornar a casar e, subsequentemente, ter acesso a outro durgavat.

Por outro lado, o nascimento de uma rapariga é recebido em silêncio, sem festividades, nem alegrias, ensombrando a nova vida (mãe e filha) em relação às despesas futuras com o dote e, como reza o ditado indiano, "ter uma filha é o mesmo que regar a horta do vizinho". ${ }^{87}$

Noutras sociedades o casamento era acompanhado pelo dote ou pelas $\operatorname{arras}^{88}$ (ainda praticadas no Brasil). $O$ dote compreendia os bens dados pelos pais da noiva a esta, e as arras, dadas pelo noivo à noiva, consistiam em bens ou um sinal em dinheiro para assegurar o contrato..$^{89}$

Semelhante à tradição dos Cabinda, na cultura romana e segundo Aldazábal ${ }^{90}$ as arras significavam as prendas (penhor, abonação) que se faziam na cerimónia dos esponsais, como antecipação e garantia da futura união matrimonial, entendidas como "fiança" ou "santo e senha" que envolvia um contrato ou uma aliança pagos pelo marido à família da mulher (enquanto esta trazia o seu dote).

No matrimónio castelhano mantém-se esse costume, renovado em 1996, enriquecido com a entrega de arras ao marido, expressando a comunhão de vida e de bens que se estabelece entre os esposos, ao proferir o seguinte: "recebe estas arras como prenda da bênção de Deus e sinal dos bens que vamos partilhar". ${ }^{91}$

Um estudo sobre a mulher e o dote em Portugal nos finais do século XVIII e início do XIX refere que "os contratos de dote, ou de dote e arras, seriam próprios de um regime de exceção", conforme o Código Civil de 1867, citado em Seabra. ${ }^{92}$ Apesar de essa época ter sido de mudança de mentalidades, a dependência da mulher em relação ao pai ou em relação ao marido ainda era bem patente pela atribuição de um dote que variava conforme a condição social, diferente entre as famílias nobres e burguesas. No primeiro caso era dividido em duas partes: "uma parte constituída pelo enxoval, joias e móveis e a outra parte composta por bens 
correspondentes às 'legítimas' e/ou terças dos pais". 93 Nas famílias burguesas havia contratos em dinheiro, ofertas de peças de ourivesaria ou de propriedades, dote que era prerrogativa das classes abastadas, ficando à margem as famílias com menos recursos económicos. ${ }^{94}$

Para resolver o oportunismo inerente a certos casamentos, por vezes autênticas "caças ao dote", o Estado português aprovou normas específicas aplicáveis ao regime de bens: casamentos com separação de bens, ${ }^{95}$ regime da comunhão de adquiridos ${ }^{96}$ ou bens integrados na comunhão. ${ }^{97}$ Legalmente, o casamento é referenciado ${ }^{98}$ como "o contrato celebrado entre duas pessoas que pretendem constituir família mediante uma plena comunhão de vida", sendo a idade mínima dos cônjuges de 18 anos e atualmente permitido entre pessoas do mesmo sexo. ${ }^{99}$

Apesar de nas sociedades europeias estar praticamente em desuso ser a noiva a reunir um enxoval para o casamento, tanto mais rico quanto o seu status social, em África, ainda hoje é ao noivo que cabe assegurar todas as despesas inerentes ao alambamento, o qual desencadeia todo o processo de casamento.

\section{Considerações finais}

Foi elaborada uma contextualização histórica sobre Cabinda, região originária do antigo Reino do Congo que abriga várias etnias cujo tronco cultural é comum, como são exemplo os povos Cabinda, os Kongo e os Woyo. Por razões sociopolíticas e por relações de parentesco, assentes na forte componente matrilinear, a história desses povos e a etnicidade que as uniu não pode ser dissociada.

Sublinhamos o desconhecimento de peças semelhantes ao dístico de casamento, objeto deste estudo, não tendo encontrado na literatura outras interpretações para além da relatada por Vaz, ${ }^{100}$ autor que descodifica essa peculiar figuração quanto aos princípios tradicionais entre os Cabinda.

Apenas detectamos um testemunho alusivo a uma placa comemorativa (placatory gift) referido por Laman, ${ }^{101}$ na sua vasta obra sobre os Kongo, embora noutro contexto, em que terá servido para comemorar a reconciliação entre cônjuges festejando a continuidade do casamento.

Tal como as imagens gravadas nas tampas de panela dos Woyo, também os motivos plásticos esculpidos na superfície da tábua representam elementos de transmissão de ideias associadas ao valor metafórico da mensagem e sua interpretação. ${ }^{102}$ Nesse sentido, as personagens em diálogo inscritas no dístico subentendem uma narrativa sobre as negociações entre as famílias dos noivos conducentes ao acordo entre ambas as partes para a efetivação do casamento. Assim, a importância do alambamento reside no fato de representar uma garantia, transação comercial ou caução impeditiva da rescisão do contrato e confirma a cedência por parte de uns e de aquisição por parte de outros.
93. Seabra (1983, p. 77).

94. Seabra (1983, p. 78).

95. Portugal (2001, artigo 1.720).

96. Portugal (2001, artigos 1.721 ao 1.735$)$.

97. Portugal (2001, artigo 1.724).

98. Portugal (2001, artigo 1.577).

99. O casamento civil em Portugal entre pessoas do mesmo sexo entrou em vigor em 2010. Portugal (2010).

100. Vaz (1970b).

101. Laman (1957, p. 37).

102. Miranda; Martins (2011, p. 464). 
103. Tavares (2016, p. 71).

104. Mack (2001, p. 8).

105. Fernando (2010, p. 9).
Qualquer que seja a forma de atribuição do alambamento em Angola, considerado ou não uma compensação, assenta em componentes de explicação sociológica a diversos níveis. Porém, a celebração do matrimónio, parametrizada por todas as condicionantes que o antecederam, termina sempre em festividade tanto a nível conjugal, como a nível social.

Em resumo, diremos que a tábua representa um certificado de alambamento entre os Cabinda: além de retratar todo o complicado processo de diálogo das famílias dos noivos, atesta a concordância de ambas, etapa obrigatória para a realização do matrimónio.

Para se dar continuidade a esta pesquisa seria imprescindível auscultar o testemunho de anciãos locais sobre o significado atual dessa prática, se o ritual se mantém, averiguar qual a família envolvida na concepção da tábua, a autoria da mesma e qual o valor eventualmente pago para a sua realização. Fica por desvendar quantas são as estórias que essa tábua simboliza e quantos casamentos acolheu, recatos que só a ela pertencem...

Tanto na África como noutros continentes existiu ou existe a obrigatoriedade de um contrato prévio entre as partes envolvidas no casamento, independentemente dos termos atribuídos (alambamento, dote, lobolo, arras...). 0 alambamento, enquanto instrumento oficial e público, com valor jurídico entre famílias ou intergrupos é, também, um sinal ritual exterior que valida e sela o contrato matrimonial de muitos povos africanos e não africanos.

Essas práticas socioculturais, com algumas diferenças, remontam a tempos antigos e a diversas civilizações, bem anteriores ao século XX, época em que esta pesquisa se situa.

A investigação realizada para a interpretação de uma tábua recolhida pelos Missionários Espiritanos em Angola, esteticamente pouco rica mas que nos intrigou pela silenciosa comunicação que expressa, permitiu-nos não só descodificar os intrincados desacordos e entendimentos de um casamento entre os Cabinda, como cruzar outras trajetórias culturais, quase sempre igualmente ligadas a interesses sociais, políticos e económicos.

Concluímos poder dizer que a estética que transparece dos objetos museológicos nem sempre corresponde à essência, ao conteúdo e ao significado da sua génese, e o contrário também deverá ser verdadeiro. Ressalta então a importância de estarmos bem atentos à realidade museológica que nos rodeia. Do mais simples ao mais sofisticado, tudo é produto da cultura humana, o desígniochave do estudo antropológico e, como em qualquer ciência, há que dar continuidade, multiplicar e proporcionar motivos de partilha, e de partida, para a fruição e exploração dos seus segredos, sempre surpreendentes e inesgotáveis. ${ }^{103}$

Terminamos com uma referência a John Mack, atual presidente do Instituto Sainsbury para a Arte (UEA) e ex-conservador (1997-2003) do British Museum, que em 2001104 preconizava que os museus, mais do que arquivos passivos das heranças culturais do passado, devem ser agentes ativos na recriação do conhecimento cultural contemporâneo. Uma década depois, Manzambi Vuvu Fernando, ${ }^{105}$ diretor nacional 
dos Museus de Angola, corrobora e amplia essa opinião, reforçando que a antropologia deverá contribuir para a desconstrução dos objetos nos museus, revisitando na literatura o modo como e por quem as coleções foram recolhidas, identificadas e articuladas pelas instituições que as acolheram.

Dando voz aos objetos, restituímo-thes a sua própria linguagem e contexto real, oportunidade para repensar o seu posicionamento e significado no mundo, correspondendo desse modo à função do museu.

\section{AGRADECIMENTOS}

A Juliana Ribeiro da Silva Bevilacqua por todo o estímulo e força com que desde o início nos motivou para esta investigação, bem como todas as sugestões que ajudaram a clarificar os vários significados representados nesse acordo de casamento. 


\section{REFERÊNCIAS}

ALDAZÁBAL, José. Dicionário elementar de liturgia. Prior Velho: Paulinas, 2007. Disponível em: <http://www.liturgia.pt/dicionario/dici_ver.php?cod_dici=31>. Acesso em: 6 jun. 2016.

ANGOLA. Lei n. 1, de 20 de fevereiro de 1988. Aprova o Código da Família. Diário da República [Popular de Angola]. Luanda, I série, n. 8, 20 fev 1988. Disponível em: <http://www. consuladogeralangola-porto.pt/download/pt/1-codigo-familia.pdf>. Acesso em: 31 maio 2016.

BARBOSA, Adriano. Dicionário Cokwe-Português. Coimbra: Instituto de Antropologia da Universidade de Coimbra, 1989. (Publicações do Centro de Estudos Africanos, 11).

BASTIN, Marie Louise. Escultura Angolana, Memorial de culturas. Lisboa: Museu Nacional de Etnologia, 1994.

BASTOS, Augusto. Traços geraes sobre a ethnographia do distrito de Benguella. Boletim da Sociedade de Geografia de Lisboa, Lisboa, s. 26, n. 3, p. 81-99, 1908.

BRASIL. Código Civil, 2002. Disponível em: <http://www.planalto.gov.br/ccivil_03/leis/2002/ 110406.htm>. Acesso em: 6 jun. 2016.

BUZA, Alfredo Gabriel; CANGA, Juliana Lando; ANTÓNIO, Maria Fátima; SITA, Helena Sameira; PADI, Serafina Cristina; BUZA, Ruth Ganga. O Tchikumbi em Cabinda: o esvaziamento de uma prática e saber tradicional de educação familiar. In: CONGRESSO LUSO-AFRO-BRASILEIRO DE CIÊNCIAS SOCIAIS, 11., 2011, Salvador. Anais do XI Congresso Luso-Afro-Brasileiro. Salvador: Universidade Federal da Bahia, 2011. Disponível em: <http://www.docdatabase.net/ more-o-tchikumbi-em-cabinda-o-esvaziamento-de-uma1126831.html>. Acesso em: 15 mar. 2016.

CAVAZZI, João António. Descrição histórica dos três Reinos do Congo, Matamba e Angola (1622-1678). Lisboa: Junta de Investigações do Ultramar, 1965. 2 v.

DIAS, Jill. África: nas vésperas do mundo moderno. Lisboa: Comissão Nacional para as Comemorações dos Descobrimentos Portugueses, 1992.

DICIONÁRIO Priberam da Língua Portuguesa, 2008. Disponível em: <http://www.priberam. pt/dlpo/arr\%C3\%A1s>. Acesso em: 31 maio 2016.

DITTMER, Kunz. Etnología general: formas y evolución de la cultura. México: Fondo de Cultura Económica, 1960. 
FERNANDO, Manzambi Vuvu. Por detrás das Imagens, o Significado dos Objetos Etnográficos nos Museus: uma reflexão sobre coleções africanas. In: FALGAYRETTES-LEVEAU, Christiane (Ed.). Angola, figures de pouvoir. Paris: Éditions Dapper, 2010, p. 6-11.

FERREIRA DINIZ, José de Oliveira. Populações Indígenas de Angola. Coimbra: Imprensa da Universidade, 1918.

FRANQUE, Domingos José. Nós, os Cabindas: História, Leis, Usos e Costumes dos Povos de N’Goio. Lisboa: Argo, 1940.

GERBRANDS, Adrian Alexander. Art as an element of culture, especially in Negro-Africa. Leiden: E. J. Brill, 1957.

HILTON, Anne. Family and Kinship among the Kongo South of the Zaire River from the sixteenth to the nineteenth centuries. The Journal of African History, [S.1.]: Cambridge University Press, v. 24, n. 2, p. 189-206, 1983.

JACMIN, Tatia Paule. A queima das noivas: grande reportagem. Lisboa: [s.n.], 1994, p. 60-70.

KOPYTOFF, Igor. The cultural biography of things: commoditization as process. In: APPADURAI, Arjun (Ed.). The social life of things: commodities in cultural perspective. Cambridge (UK): Cambridge University Press, 1986, p. 64-87.

LAMAN, Karl. The Kongo II. Stockholm: Hakan Ohlssons Boktryckeri Lund, 1957.

LEHUARD, Raoul. Art Bakongo: Les centres de style. Arnouville: Arts d'Afrique Noire, 1989. 2 v.

Les Phemba du Mayombe. Arnouville: Arts d'Afrique Noire, 1977, p. 7-123. Supplément au tome 17, Mars.

MACGAFFEY, Wyatt. Lineage Structure, Marriage and the Family Amongst the Central Bantu. The Journal of African History, [S.1.], Cambridge University Press, v. 24, n. 2, p. 173-187, 1983.

MACK, John. Foreword. In: SHELTON, Anthony (Ed.). Collectors, Individuals and Institutions. London: The Hornimam Museum and Gardens; Coimbra: Museu Antropológico da Universidade de Coimbra, 2001, p. 7-8.

MARTINS, Joaquim. Cabindas: História, Crenças, Usos e Costumes. Angola: Comissão de Turismo da Câmara Municipal de Cabinda, 1972.

MARTINS, Maria do Rosário; CRUZ, Maria das Dores. Adornos africanos como entidade cultural. Coimbra: Museu e Laboratório Antropológico da Universidade de Coimbra, 1989. 
MBAMBI, Moisés. O Alambamento nos direitos africanos. 2007. Disponível em: <http://www. fd.ulisboa.pt/wp-content/uploads/2014/12/Moises-Mbambi-O-ALAMBAMENTO-NOSDIREITOS-AFRICANOS.pdf>. Acesso em: 31 maio 2016.

MIRANDA, Maria Arminda; MARTINS, Maria do Rosário. Mabaia Manzungu: tratado de deveres e direitos. II Seminário de Investigación en Museologia de los Países de lengua Portuguesa y Española. Buenos Aires, Comité Internacional del ICOM para la Museologia - ICOFOM, 2011, p. 462-473, 2011. Disponível em: <http://ler.letras.up.pt/uploads/ficheiros/10273.pdf>. Acesso em: 24 julho 2017.

Objetos de mujeres: Vidas en diálogo. In: CAJA de Ahorros de Asturias (Ed.). África: Objetos y Sujetos. Oviedo: Caja de Ahorros de Asturias, 2010, p. 85-93; 347-350; 405408. Trilíngue.

MILHEIROS, Mário. O casamento no direito gentílico angolano. In: ANGOLA. Direcção dos Serviços de Administração Civil. Centro de Informação e Turismo de Angola. Fundo de Turismo e Publicidade. Mensário Administrativo. Luanda: Centro de Informação e Turismo de Angola, 1948 , n 5, p. 23-26.

OLIVEIRA, José Carlos. Os Zombo. 2010. Disponível em: <http://www.estudosafricanos. com/?p=39>. Acesso em: 26 out. 2010.

POLANAH, Luís. O nhamussoro e as outras funções mágico-religiosas. Coimbra: Instituto de Antropologia da Universidade de Coimbra, 1987. (Publicações do Centro de Estudos Africanos, 7).

PORTUGAL. Código Civil Português. Coimbra: Livraria Almedina, 2001.

Lei n. 9, de 31 de maio de 2010. Permite o casamento civil entre pessoas do mesmo sexo, alterando os artigos 1.577, 1.591 e 1.690 e revogando a alínea e) do artigo 1.629 do Código Civil. Diário da República [Portuguesa], $1^{\text {a }}$ Série A, n. 105, 31 maio 2010, p. 1853. Disponível em: <http://www.dgpj.mj.pt/sections/informacao-e-eventos/2010/lei-n-9-2010-de31-de/downloadFile/file/L_9_2010.pdf?nocache=1275294938.33>. Acesso em: 30 maio 2016.

REDINHA, José. Distribuição étnica de Angola. Luanda: Centro de Informação e Turismo de Angola, 1974.

SEABRA, Maria Judite Carvalho Ribeiro. A mulher e o dote na segunda metade do séc. XVIII. Coimbra: Antropologia Portuguesa, 1983, v. 1, p. 43-80.

TAVARES, Ana Cristina Pessoa. Educação em Jardins Botânicos: 16 anos de experiência. Coimbra: Edição de autor, 2016. Disponível em: <http://www.eumed.net/librosgratis/2015/1442/index.htm>. Acesso em: 30 set. 2016. 
THOMPSON, Robert Farris. La gestuelle Kôngo. In: FALGAYRETTES-LEVEAU, Christiane (Ed.). Le geste Kôngo. Paris: Éditions Dapper, 2002, p. 23-129.

UNIÃO de facto regulamentada em Angola ao fim de mais de 25 anos. Diário de Notícias. Lisboa, 9 fev. 2015. Disponível em: <http://www.dn.pt/globo/interior/uniao-de-factoregulamentada-em-angola-ao-fim-de-mais-de-25-anos4390282.html>. Acesso em: 6 jun. 2016.

VALENTE, José Francisco. A problemática do património tribal. Lisboa: I.I.C.T.; Congregação do Espírito Santo, 1985.

VAZ, José Martins. Filosofia Tradicional dos Cabindas. Lisboa: Agência Geral do Ultramar, 1969. V. I

Filosofia Tradicional dos Cabindas. Lisboa: Agência Geral do Ultramar, 1970a. V. II

No Mundo dos Cabindas: estudo etnográfico. Lisboa: Editorial L.I.A.M., 1970b. V. I.

. No Mundo dos Cabindas: estudo etnográfico. Lisboa: Editorial L.I.A.M., 1970c. V. II.

VISSERS, João. Alambamento e Amor Conjugal. Separata de: Portugal em África. Lisboa, 2. série, v. 21, n. 123/124, p. 134-147, 1964.

Artigo apresentado em 04/1 1/2016. Aprovado em 27/04/2017 